POPULAR SUMMARY:

North American vegetation dynamics observed with multi-resolution satellite data

Christopher S.R. Neigh, NASA Goddard Space Flight Center

North American vegetation has been discovered to be a net carbon sink, with atypical behavior of drawing down more carbon from the atmosphere during the past century. It has been suggested that the Northern Hemisphere will respond favorably to climate warming by enhancing productivity and reducing the impact of fossil fuel emissions into the atmosphere. Many investigations are currently underway to understand and identify mechanisms of storage so they might be actively managed to offset carbon emissions which have detrimental consequences to the functioning of ecosystems and human well being.

This paper used a time series of satellite data from multiple sensors at multiple resolutions over the past thirty years to identify and understand mechanisms of change to vegetation productivity throughout North America. We found that humans had a marked impact to vegetation growth in half of the six selected study regions which cover greater than two million $\mathrm{km} 2$. We found climatic influences of increasing temperatures, and longer growing seasons with reduced snow cover in the northern regions of North America with forest fire recovery in the Northern coniferous forests of Canada. The Mid-latitudes had more direct land cover changes induced by humans coupled with climatic influences such as severe drought and altered production strategies of rain-fed agriculture in the upper Midwest, expansion of irrigated agriculture in the lower Midwest, and insect outbreaks followed by subsequent logging in the upper Northeast. Vegetation growth over long time periods (20+ years) in North America appears to be associated with long term climate change but most of the marked changes appear to be associated with climate variability on decadal and shorter time scales along with direct human land cover conversions. Our results document regional land cover land use change and climatic influences that have altered continental scale vegetation dynamics in North America. 


\title{
North American vegetation dynamics observed with multi-resolution satellite data
}

\author{
Christopher S. R. Neigh ${ }^{1,2,3}$, Compton J. Tucker ${ }^{1,2}$, and John R. G. Townshend ${ }^{2}$ \\ ${ }^{1}$ Hydrospheric and Biospheric Sciences Laboratory, \\ Code 614.4,Greenbelt, Maryland 20771 \\ ${ }^{2}$ Department of Geography, University of Maryland, \\ College Park, Maryland 20741 \\ ${ }^{3}$ Science Systems Application Inc., Lanham, Maryland, 20706 \\ Contact: neigh@gsfc.nasa.gov
}

\begin{abstract}
We investigated normalized difference vegetation index data from the NOAA series of Advanced Very High Resolution Radiometers and found regions in North America that experienced marked increases in annual photosynthetic capacity at various times from 1982 to 2005. Inspection of these anomalous areas with multi-resolution data from Landsat, Ikonos, aerial photography, and ancillary data revealed a range of causes for the NDVI increases: climatic influences; severe drought and subsequent recovery; irrigated agriculture expansion; insect outbreaks followed by logging and subsequent regeneration; and forest fires with subsequent regeneration. Vegetation in areas in the high Northern Latitudes appear to be solely impacted by climatic influences. In other areas examined, the impact of anthropogenic effects is more direct. The pattern of NDVI anomalies over longer time periods appear to be driven by long term climate change but most appear to be associated with climate variability on decadal and shorter time scales along with direct anthropogenic land cover conversions. The local variability of drivers of change demonstrates the difficulty in interpreting changes in NDVI and indicates the complex nature of changes in the carbon cycle within North America. Coarse scale analysis of changes could well fail to identify the important local scale drivers controlling the carbon cycle and to identify the relative roles of disturbance and climate change. Our results document regional land cover land use change and climatic influences that have altered continental scale vegetation dynamics in North America.
\end{abstract}

Keywords: AVHRR, NDVI, Vegetation Dynamics, Land Cover, Climate, Landsat 


\section{Introduction}

Land cover and land use change strongly influence terrestrial biogeophysical and biogeochemical process (Brovokin et al., 2004; DeFries et al., 1999; Houghton, 1999). Humans and changing climate, separately or in concert, have affected global vegetation, biogeochemical cycles, biophysical processes, and primary production. To infer North America vegetation changes we used a 1982 to 2005 record of normalized difference vegetation index (NDVI) data. This approach, using 8-km NDVI data from the (NOAA) National Ocean and Atmospheric Administration Advanced Very High Resolution Radiometer (AVHRR) instruments, has previously identified large-scale spatial and temporal patterns of vegetation response to climate (Lotsch et al., 2005; Myneni et al., 1997; Nemani et al., 2003; Zhou, 2003). Previous work by others, (Goetz et al., 2005; Gong \& Shi, 2003; Ichii et al., 2002; Myneni et al., 1997; Nemani et al., 2003; Slayback et al., 2003; Tucker et al., 2001; Zhou et al., 2001), has addressed continental scale phenomena of changes in photosynthetic capacity since 1981-1982 from NDVI data. Investigations with coarse resolution data are limited in the ability to identify specific regional or local land use and land cover change mechanisms that could be responsible for NDVI anomalies.

A number of natural factors influence North American vegetation and primary production, and hence the NDVI: warming and possible reduced arctic snow cover (Chapin et al., 2000; Dye \& Tucker, 2003); altered plant communities structure (Epstein et al., 2004; Sturm et al., 2005; Sturm et al., 2001; Tape et al., 2006); reduced permafrost extent and effects upon vegetative growth (Hobbie et al., 2002; Stokstad, 2004); insect and pathogen outbreaks (Ayres \& Lombardero, 2000); severe drought (Angert et al., 2005; Barber et al., 2000; Ciais et al., 2005; Dai et al., 2004; Lotsch et al., 2005); and forest fire regimes (Flannigan et al., 2000). Anthropogenic influences on vegetation productivity include: more intensive agriculture practices (Malhi et al., 2001; Sainju et al., 2002); expansion of irrigated agriculture 
64 (Lemly et al., 2000; Tilman, 1999); decreasing productivity by removing biomass through urban

expansion (Imhoff et al., 2000; Masek et al., 2000); and logging and subsequent regeneration (Howard et al., 2004). This analysis was undertaken to understand vegetation dynamics at a regional scale in North America, to explore possible mechanisms that can affect continental-scale primary production. We were specifically interested in investigating NDVI anomalies and determining what caused them, through the combined use of AVHRR NDVI, Landsat, Ikonos, aerial photography, and ancillary data. NDVI data from the NOAA series of AVHRR instruments over the past 24 years have shown variations in photosynthetic capacity across large areas of North America (Slayback et al., 2003). These . observed NDVI trends have occurred in a variety of regions, implying possibly a variety of cause(s) (Goetz et al., 2005; Picket \& White, 1985; Tucker et al., 2001). Although a number of recent studies have found marked variations in NDVI throughout the Northern Hemisphere, they have not attributed these changes to regional factors that may include natural disturbances and/or human alterations to ecosystem functioning (Gong \& Shi, 2003; Lotsch et al., 2005; Lucht et al., 2002; Myneni et al., 2001; Myneni et al., 1997; Nemani et al., 2003; Slayback et al., 2003; Tucker et al., 2001; Zhou et al., 2001). It is important to identify and quantify land cover type, because changes in land cover can alter ecosystem functioning and carbon storage (Baldocchi \& Amthor, 2001; Olson, 1975). NDVI (Tucker, 1979) is calculated from channel $1(0.58-0.68 \mu \mathrm{m})$ and channel $2(0.72-1.10 \mu \mathrm{m})$ from the NOAA AVHRR series of polar orbiting satellites as:

$$
\text { NDVI }=\frac{(\text { Channel } 2-\text { Channel 1) }}{(\text { Channel } 2+\text { Channel } 1)}
$$

NDVI has been found to have a strong linear relationship to the fraction of photosynthetically active radiation (FPAR), the radiation that drives photosynthesis $(0.4-0.7 \mu \mathrm{m})$ (Myneni et al., 1995; Sellers, 1985). FPAR is the main determinant of net primary productivity (NPP) of the ecosystem (Monteith, 
1981). NDVI changes across North America are thus important because they represent variability in vegetation photosynthetic capacity. Few investigations have explored regional vegetation changes in North America responsible for the observed increases in Northern Hemisphere NDVI; (Jia et al., 2003;

Stow et al., 2003; Walker et al., 2003) our investigation seeks to understand regional vegetation dynamics across the North American Continent observed by AVHRR NDVI.

\section{Methods and Data}

\subsection{AVHRR NDVI}

We used the Global Inventory Modeling and Mapping Studies (GIMMS) version "g", 1982 to 2005 bimonthly AVHRR NDVI record (Tucker et al., 2005) because a consistent inter-calibrated data set is critical for long-term vegetation studies. These data, at $8-\mathrm{km}\left(64 \mathrm{~km}^{2}\right)$ resolution and bimonthly intervals, have been processed to account for orbital drift, minimize cloud cover, compensate for sensor degradation, and effects of stratospheric volcanic aerosols (Brown et al., 2004; Tucker et al., 2005). The

101 GIMMS NDVI data records are accessible from the University of Maryland's Global Land Cover

102 Facility (www.landcover.org).

The first step in our analysis was to identify regions for further investigation. Next we used

104 Landsat data to understand NDVI anomalies in terms of land cover at the $30 \mathrm{~m}$ scale. Anomaly images were generated by year relative to the 1982 to 2005 average May to September NDVI for North

106 America. Areas were selected for further study if they met 2 criteria: 1) a contiguous region $>2,000$

$107 \mathrm{~km}^{2}$ with a $>0.1$ NDVI anomaly at a $98 \%$ confidence interval; and 2) high resolution remote sensing 108 data and corresponding validation were also available for analysis for the 1982 to 2005 time period. 109 Specific time periods were selected to investigate the occurrence of the respective NDVI anomalies. 
A lengthening of the growing season may increase plant growth, increase biomass formation,

111 and increase carbon sequestration (Menzel \& Fabian, 1999). Nemani, et al. (2003), suggested multiple mechanisms affecting net primary productivity (NPP): nitrogen deposition, $\mathrm{CO}_{2}$ fertilization, forest regrowth, temperature, precipitation and solar radiation. Recovery from disturbance in forest ecosystems has been noted to produce a net terrestrial carbon sink by which net primary production (NPP) exceeds heterotrophic respiration (Rh) due to enhanced resource availability, and reduced detritus

116 input into the soil (Odum, 1969). We selected regions with increasing NDVI to explore possible 117 changes in ecosystem functioning due to conversion and/or recovery of vegetation.

\subsection{Landsat}

Landsat data were acquired for the same areas that had $>0.1$ NDVI anomaly values. We first used data from NASA's orthorectified global Landsat data set (also called the "Geocover" data set) because these data have a $<50 \mathrm{~m}$ root mean square location error among the 1970s, 1990, and 2000 data layers (Tucker et al., 2004) and are available free of charge from the Global Land Cover Facility at the

University of Maryland. We acquired additional Landsat data for other time periods as needed and coregistered these data to the corresponding Geocover data.

We developed a methodology to determine land cover for three time periods ( $>150$ scenes), to quantify land cover changes that could be responsible for trends in NDVI. We used the International

128 Geosphere Biosphere (IGBP) classification because of its simplicity in defining North American vegetation types. These vegetation types include: evergreen needleleaf forest; mixed evergreen needleleaf and broadleaf deciduous forest; broadleaf deciduous forest; dwarf trees and shrubs; short

131 vegetation C4 grasslands; agriculture C3 grasslands; water; barren lands; clouds and snow and ice 132 (Table 1). 
An additional coregistration between images was carried out between images to avoid

134 misregistration errors that could be confused with land cover change (Townshend et al., 1992). A

135 minimum of 25 ground control points distributed over the image were selected between the

136 orthorectified base image and the added image. A root mean square error of less than 0.25 pixels was

137 used as the maximum threshold for error before the image was used in our analysis. All Landsat images

138 were processed in a similar manner with the same accuracy.

139 When using multispectral data, changes in surface reflectance have been associated with changes

140 in vegetation cover and extent. Generally, a higher reflectance is associated with sparse vegetation

141 cover, and a lower reflectance is associated with dense vegetation or water in visible wavelengths.

142 When investigating pixel response to changes in land cover, deforestation will typically increase pixel

143 brightness (darker vegetation to lighter soil) whereas afforestation and succession would decrease pixel

144 brightness (bare soil to vegetation) (Jensen, 2006). We use this simple observation to quantify variance

145 in land cover. Radiance values are used in our analysis because the selected study sites have marked

146 changes in land surface reflectance observed by AVHRR. The spectral changes observed between

147 vegetated and non-vegetated pixels far outweigh the influences of sun angle, variability in atmospheric

148 attenuation, and sensor degradation.

149 A number of change detection transforms have been applied to Landsat data: Principal

150 Component Anaylsis (PCA), tassel cap (TC), and change vector analysis (CVA) (Crist \& Cicone, 1984;

151 Kauth et al., 1978; Richards, 1984). These methods all identify change in multi-temporal data and have

152 been enhanced with hybrid methods (Guild et al., 2004; Jin \& Sader, 2005; Lanjeri et al., 2004; Lunetta

153 et al., 2002; Nackerts et al., 2005; Rigina, 2003; Warner, 2005). Our analysis developed two methods to

154 stratify multispectral observations into thematic maps of land cover and land cover change. The first

155 method was developed for the boreal zone where variance in spectral reflectance is observed from forest 
156 to non-forest changes. Method two required adaptation to identify interannual land use changes that

157 may be difficult to distinguish in regions of intense agriculture. Deriving an assessment of annual active

158 productivity within a region of crops that are rotated seasonally requires an approach to capture all of the

159 active croplands from native short and tall grass prairies. Both methods are based on change detection

160 algorithms currently in use (Guild et al., 2004; Lanjeri et al., 2004).

161 A base map was first generated from the 2000 image from the red (Channel 3), near infrared

162 (Channel 4), and mid infrared (Channel 5) from the Landsat Enhanced Thematic Mapper plus (ETM+).

163 An unsupervised ISODATA classification was performed with all three channels. ISODATA is a

164 standard clustering algorithm available in most image processing software packages and is based on

165 procedures in which cluster centers are iteratively determined sampled means (Tou \& Gonzales, 1974).

166 If a scene contains atmospheric constituents, multiple iterations of the classification were performed to

167 mask and eliminate cloud, cloud shadow, and haze cover. This was necessary to minimize atmospheric

168 contamination that alters the class distribution structure. That was the basis for selecting and

169 distinguishing the classification cover types.

170 Once a base map of recent land cover was derived, we reverted in time to define locations of

171 change in land cover and mask the current thematic map for prior land cover types (Fig. 1). A similar

172 method has been performed by (Lanjeri et al., 2004). This method was applied to reduce

173 misclassifications between dates with no land cover changes.

174 Change detection was subsequently performed once a base thematic map had been developed for

175 each anomaly area. A linear tassel cap transformation was first applied to the temporal images reducing

176 multispectral redundancy to indices of brightness, greenness, and wetness (Crist \& Cicone, 1984; Huang

177 et al., 2002). The linear tassel cap also enhanced differences in brightness, greenness, and wetness that

178 may occur between multi-date images. The weights of the linear tassel cap transformation were fixed, 
were sensor specific, and were not scene dependent (Guild et al., 2004). The sensor specific weights of

180 the linear tassel cap transformation aid in normalizing between sensors for change detection analysis.

181 Finally, an unsupervised ISODATA clustering algorithm was performed to all transformed images to

182 group similar spectral vectors into 'change' and 'no change' clusters from the bi-temporal images

183 (Richards, 1993).

184 The same procedure was also performed in agriculture regions with the modification of adding 185 an additional pair of images from the same year as the base period of investigation (Fig. 2). This was

186 done to capture crop rotation during a growing season while distinguishing irrigated agriculture from 187 fallow croplands and natural grasslands. Irrigated agriculture generally has an enhanced signature of 188 wetness and greenness compared to non-irrigated vegetation in the semi-arid high plains environment.

189 The additional image required image processing to produce a meaningful bi-temporal tassel cap image.

\subsection{Validation}

192

Accuracy assessment of land cover maps incorporated two levels of stratification. This was performed to capture two separate indicators of accuracy: map accuracy; and an assessment of change.

194 The sample design contains three components similar to Stehman \& Wickham, (2006), that were used for the National Land Cover Assessment: (1) the sample design, that determines the spatial locations at which the reference data were obtained; (2) the response design, that details how the reference data were

197 obtained; and (3) the analysis plan for producing the accuracy assessments. Error matrices are then created between the thematic map and reference data. Matrices are constructed with the rows representing the map land cover and columns representing the reference land cover.

201 Each study region was subdivided into two by two degree cells. The spatial extent of the maps 
202 developed for analysis in this investigation were large with study areas ranging from $\sim 8$ to $\sim 18$ million

203 hectares $\left(62,136 \mathrm{~km}^{2}\right.$ to $\left.111,846 \mathrm{~km}^{2}\right)$. Multiplied times six study regions, and three temporal periods

204 produced maps containing $\sim 324$ million hectares $\left(2,013,202 \mathrm{~km}^{2}\right)$. An adequate sampling of validation

205 data from in situ field surveys was impractical and cost prohibitive due to the spatial extent of the maps.

206 A cost effective large sampling method was employed to develop an adequate validation reference

207 dataset for cross comparison.

208 The validation dataset was derived from very high-resolution $(\sim 0.5-2 \mathrm{~m})$ archived digital aerial

209 photography, Ikonos high resolution remote sensing imagery (1-4 m), and in situ field plot surveys with

210 aerial over flights of Global Position System (GPS) referenced photography. The 2000 Landsat analyses

211 were validated the most, because they were the most current satellite information (Fig. 3). The 1990 and

2121975 Landsat data was investigated with digital aerial photography from a similar time period to verify

213 observed changes in cover types. Unfortunately a very limited amount of high-resolution aerial

214 photography data existed for our selected study regions in 1975. This limitation was reported in

215 accuracy assessments as the number of samples used in the confusion matrix as comparisons of dates

216 between air photos and Landsat scenes. Accuracy assessment of historical maps is vital due to the

217 implications of land cover land use change within disturbance-modified ecosystems. Biogeochemical-

218 modeled results rely on remote sensing input datasets to derive quantitative estimates of carbon (Potter

219 et al., 1993; Powell et al., 2004).

220

221

\subsection{Ancillary Data}

222 Once the primary cause of land cover change was identified with Landsat regional analysis, we

223 used fire, logging, agriculture production, temperature, and precipitation data to investigate these factors

224 as possibly contributing to NDVI trends within the areas studied. Fire and logging extent datasets were 
225 derived from the Canadian forest service (Canada, 2006; NRC, 2006) and were reported annually by

226 province in hectares. A fire database from the boreal ecosystem-atmosphere study (BOREAS) that 227 spans from 1945 to 1996 was also used (Sellers et al., 1997). Agriculture production data were derived 228 from the United States Department of Agriculture (USDA) National Agriculture Statistics Service 229 (NASS) (USDA, 2006) for areas selected for study in the U.S. Data were reported by county, crop 230 type, and production method.

231 Influences of temperature and precipitation were investigated with daily meteorological station data 232 (where available) from the Meteorological Service of Canada (MSC) in regions with NDVI trends with 233 no land cover change (MSC, 2007). Analyses were performed to investigate whether drought, or a 234 change in growing season length had occurred. The beginning of the growing season was calculated as

235 the first appearance of five consecutive days with the daily average surface temperature, $236 T=\left(T_{\max }+T_{\min }\right) / 2$, above $5^{\circ} \mathrm{C}$ and the end of the growing season as the last occurrence of five consecutive 237 days of temperature with $T>5^{\circ} \mathrm{C}$ (Feng \& Hu, 2004; Frich et al., 2002).

\section{3. Results}

240 NDVI anomalies in the AVHRR data revealed six areas for investigation with high-resolution

241 data to evaluate land cover land use change. We selected six contiguous regions based on two

242 assumptions: (I) A contiguous region $>2,000 \mathrm{~km}^{2}$ has an NDVI trend greater than $>0.1$ from selected 243 observational periods and; (II) High resolution remote sensing data and corresponding validation data 244 were available for intensive analysis for the entire AVHRR record. Six regions met these criteria: (1) 245 the Mackenzie River delta; (2) Northern Saskatchewan; (3) Southern Saskatchewan; (4) Oklahoma 246 Panhandle; (5) Southern Quebec; and (6) Newfoundland (Fig. 4). Two areas that experienced large- 
247 scale NDVI trends were not investigated due to a lack of high-resolution remotely sensed data (Northern

248 Quebec and Labrador).

\subsection{The Arctic slope of Alaska, Yukon, and Northwest Territory}

A large area of North America bordering the Arctic Ocean in Alaska and Canada, roughly from $60^{\circ}$

252 to $70^{\circ} \mathrm{N}$ exhibited a zone of NDVI increases from 1982 to 2005 . We selected the Mackenzie River

253 Delta area of Canada for investigation, because numerous high-resolution aerial photographs are

254 available for the entire AVHRR record.

255 The Mackenzie River delta study region is located in the Arctic Circle where extreme variations 256 in solar insulation and temperature are the norm. Winter extends nine months in this region, and the 257 surrounding landscape is underlain with continuous permafrost while the land cover consists primarily 258 of alpine tundra to open lichen woodland (Archibold, 1995). The river delta has a unique ecosystem to 259 neighboring lands due to the northward flow of warm waters to the Arctic Circle. The depth of the - 260 permafrost controls nutrient availability and vegetative cover while temperature exerts considerable 261 control over permafrost depth and the active organic soil layer in surrounding ecosystems (Pavelsky \&

262 Smith, 2004). Chen et al., (2003), noted a decline of 22\% in the permafrost zone from 1940 to 1995 in

263 northwestern Canada. Higher temperatures have increased the active soil layer depth and extent while 264 extending growing season length.

This area is located just above the Northern limit of the North American boreal forest and has

266 little anthropogenic disturbance. The largest concentration of human settlement in the region is Inuvik

$267\left(68^{\circ} 18^{\prime} \mathrm{N}, 133^{\circ} 30^{`} \mathrm{~W}\right)$, which has 3,600 residents (Fig. 5, A). The lack of human occupation implies the 268 observed anomaly was not associated with human alterations of land cover but the change in vegetation 269 was related to climate. 


\subsubsection{Land Cover}

272

Land cover results for this region indicated minor changes in vegetation cover from 1976 to

2000. $~ 80,000 \mathrm{~km}^{2}$ were mapped and dwarf trees and shrubs increased by $\sim 720 \mathrm{~km}^{2}(+<1 \%$ change in area), short vegetation grassland declined $\sim 950 \mathrm{~km}^{2}$ (-1\% change in area), and water extent changed by $\sim 400 \mathrm{~km}^{2}\left(+<1 \%\right.$ change in area). The largest event was a fire that burned $\sim 710 \mathrm{~km}^{2}$, reducing vegetation to barren lands $(+<1 \%$ in area).

Landsat.imagery was limited in applicability to define the spectral differences between short vegetation grasslands and dwarf trees and shrubs. This excludes the ability to define subtle vegetative growth on a decadal basis. Extensive multi-temporal high-resolution data are needed to evaluate if expansion of shrub lands is occurring. This remote area has incurred limited human disturbance implying that alterations to this ecosystem have been induced by abiotic factors. Plant growth is increasing as warmer temperatures extend the growing season length (Fig. 5, E, F, and G).

Higher surface temperatures during late winter and early spring have been reported in the high arctic of North America (Hansen et al., 1999). We found an increase in warmer temperatures was associated with a corresponding increase in NDVI in this region. Warming resulted in an earlier start of the growing season. We found temperatures increased $\sim 2^{\circ} \pm 1^{\circ}$ from March to August while the beginning of growing season was $\sim 15$ days earlier (from mid May to early May) over the same 19821999 time period. Warming in this region enhanced May to August NDVI by permitting a longer growing season (Fig. 5, G). Our results capture an increase in photosynthetic capacity (duration and amplitude) of vegetation due to longer available periods of productive growth due to earlier onset of spring. An in depth quantitative analysis of climate influence to vegetation productivity is beyond the 
293 suggested by Sturm et al., (2005), abiotic and/or sun-target-sensor influences have altered vegetation

294 dynamics in this region.

\subsection{Northern Saskatchewan}

The northern Saskatchewan study region lies on the boundaries of two ecoregions, the closed

298 boreal forest and the open lichen woodland. The division between closed spruce-feather moss boreal

299 forests and open lichen woodland is abrupt in the northern boundaries of the provinces of Manitoba and

300 Saskatchewan. This boreal ecoregion is a small portion of the North American boreal forest that covers

$301 \sim 10^{\circ}$ of latitude, but it is a floristically poor biome (Jarvis et al., 2001). Two species are nearly

302 ubiquitous in this region, white spruce ( $P$. glauca) and black spruce ( $P$. marinana) with other species of

303 larch or tamarack (L. laricina), balsam fir (A. balsamea), balsam poplar (P. banksiana), trembling aspen

304 (P. tremuloides) and white or paper birch (B. papyrifera) are intermixed depending on the age of the

305 current successional state. Extensive peat bogs and muskegs sporadically dot the landscape among

306 dense stands of conifers as remnants of glacial times of the past.

307 There is little human interference with the land cover in this region because access is limited.

308 However, fire is one of the most important disturbances in this region (Wein \& MacLean, 1983; Wright

$309 \&$ Heinselman, 1973). Boreal forests are very productive following fire events. Amiro et al., (2000),

310 found that aboveground NPP increased linearly for the first 15 years following forest fires in Canada and

311 steady states of aboveground NPP were not present until $20+$ years after fires. Carbon storage in this

312 ecosystem is closely related to fire history, as fire is a major disturbance that alters community structure

313 and vegetative productivity.

314 The average fire frequency is $\sim 60$ years depending on forest type in North American boreal

315 forests (Archibold, 1995). Fire frequency in the boreal zone has increased due to increased warming and 316 associated drying over the past 20 years (Amiro et al., 2001). Typically 9,000-10,000 fires burn in 
317 coniferous forest across Canada, which annually consume more than $20,000 \mathrm{~km}^{2}$ or $0.6 \%$ of the forested

318 area (Higgins \& Ramsey, 1992). This variation in stand age with fire revisit times can be seen in conifer

319 energetics, as peak photosynthesis has been observed in NDVI to vary throughout the life cycle of

320 boreal stands (Kasischke, 1997).

321

322

\subsubsection{Land Cover}

323

Land cover analyses for this region indicate marked changes in vegetation cover. $\sim 160,000 \mathrm{~km}^{2}$ were mapped with the largest changes occurring between short vegetation grasslands and needle leaf evergreen forests. During our study, needleleaf evergreen forests declined by $\sim 13,000 \mathrm{~km}^{2}(-8 \%$ change in area), dwarf trees and shrubs declined by $\sim 8,000 \mathrm{~km}^{2}(-5 \%$ change in area), while short vegetation

327 grasslands increased by $\sim 2,000 \mathrm{~km}^{2}(+13 \%$ change in area) (Fig. 6, C). Extensive wildfire burn scars were observed in Landsat TC data as decreases in brightness, greenness, and wetness. All anniversary scene pairs over the thirty-year period revealed extensive burn scars from boreal fires. No other apparent changes in land cover or land use were observed, as this region is located in a remote region outside the impact zone of anthropogenic land use change. Ancillary data from the Canadian Forest

332 Service indicated extensive burn scars in this region. We found recently burned forest with recovering 333 young forest stands to be the cause for the observed NDVI anomaly.

\subsubsection{Fire/Logging}

Large fires (>200 hectares) were noted in 1980, 1981, 1993, 1994, and 1995 (Fig. 6, E), while area logged for all of Saskatchewan has remained relatively stable, fluctuating between $160 \mathrm{~km}^{2}$ and 250

$338 \mathrm{~km}^{2}$ per year. The most extensive fire occurred in 1981 , burning over $22,455 \mathrm{~km}^{2}$ or over three hundred 
339 fifty, $8 \mathrm{~km}^{2}$ AVHRR pixels across the entire province. The second most extensive fire event occurred in 3401995 burning over $16,400 \mathrm{~km}^{2}$.

341 A fire event spatial database from the BOREAS was used as a surrogate to the Landsat land 342 cover evaluation (Sellers et al., 1997). A similar method to Domenikiotis et al., (Domenikiotis et al., 343 2002) was used to verify the spatial extent of fire events. Similar results to the Landsat data in annual

344 fire extent support that fire recovery is producing increases in NDVI. A majority of the large fire events 345 occurred in Northern Saskatchewan. Large-scale wildfires are a natural part of this ecosystem 346 reoccurring at intervals that are started from a number of different means and can be observed in NDVI 347 data (Kasischke, 1997). Fire recovery in this study region was the primary factor in the observed 348 increases in NDVI. We also observed higher near infrared reflectance values in Landsat data for 349 recovering vegetation in burned regions than for forests that were not burned (Fig. 6, F and G).

350 Growth is often limited in coniferous forest by mineral poor soils with productivity controlled by 351 nutrient cycling (Cole \& Rapp, 1981). Deep beds of feather mosses of Schreber's feather moss $(P$. 352 schreberi) and mountain fern moss (H. splendens) typically form the understory of forests within this 353 study area. These mosses insulate the ground and reduce decomposition because of low soil 354 temperatures. Fires release nutrients stored in mosses much faster than decomposition and therefore 355 enhance growth at post fire sites (Auclair et al., 1976; vanCleve et al., 1983). Albedo declines in burn 356 scar sites and this can increase the soil temperature by absorbing more solar radiation. AVHRR NDVI 357 anomalies observed from 1982 through 2005 were from these ecosystems that were in recovery from the 358 extensive fires that occurred in 1980 and 1981. The anomalies observed in this case were not due to 359 direct abiotic influences on productivity; they are attributable to ecosystem recovery and nutrient 360 enhancement from large-scale fire disturbance events. 361 


\subsection{Southern Saskatchewan \& the Dakotas}

The Southern Saskatchewan and Dakotas study region lies in the northern boundaries of the Great Plains. This area is commonly referred to as the 'Prairie Pothole' region because of ancient glacial depressions. Several hundred thousand small $(<100 \mathrm{ha}$ ), shallow (maximum depth $<5 \mathrm{~m}$ ) pothole lakes lie in depressions that extend over 776,900 $\mathrm{km}^{2}$ in the American Midwest and Western Canada (Covich et al., 1997). Stream drainage is primarily absent in this region, and numerous wetlands have formed between mounds of glacial till that dot the landscape. A diverse aquatic ecosystem exists here where playas, pothole lakes, ox-bow lakes, springs, groundwater aquifers, and intermittent and ephemeral streams are responsive to climatic fluctuations (Winter \& Rosenberry, 1998). Many of the wetlands are underlain by low-permeability glacial till making groundwater exchange slow. This forces these wetlands to be highly dependent upon precipitation for their water supply. Precipitation and evapotranspiration act as the largest forcing on the extent of surface water (Covich et al., 1997; Winter \& Rosenberry, 1998).

Most of the prairie that existed before human occupation has been replaced with agro ecosystems where vegetation productivity is controlled with fertilizers and irrigation (Goudrian et al., 2001). Agro ecosystems are managed and improved with new technology to produce crops nearer to their maximum physiological potential. Changes in land use in agro ecosystems to enhance productivity are achieved by: extensification (expanding the area of cultivated land); and/or intensification (increasing the number of cropping cycles sown on a particular area of land or by increasing the yield per unit area), or both (Gregory et al., 1999).

This region is heavily modified by agriculture where upland areas produce primarily sorghum, corn and wheat. During the growing season, precipitation is a limiting factor to growth. Irrigation networks are currently not extensively developed as this region has enough rainfall to support most 
crops compared to the Southern High Plains. Average annual rainfall ranges from $33-58 \mathrm{~cm}$. A

386 majority of the time, evaporation exceeds precipitation ranging from 0 to $60 \mathrm{~cm}$ (Covich et al., 1997).

387 Droughts are common throughout the high plains. Trenberth et al., (1988), noted a drought in 1988 in

388 the northern and eastern high plains; this was the only climatic event in the region concurrent with the

389 AVHRR NDVI observations. This region is well populated around urban centers and agriculture is the

390 primary land cover type. The NDVI anomaly followed the Missouri Coteau, a large topographic feature

391 that was formed by glacial deposition. It separates two major biogeographic zones of the Great Plains

392 and Central Lowlands (Fig. 7, A).

393

394 3.3.1. Land Cover

395 Land cover results for this region indicated marked changes in vegetation cover. $\sim 90,000 \mathrm{~km}^{2}$

396 were mapped, and during observations agriculture fluctuated by $\sim 7,460 \mathrm{~km}^{2}$ and stabilized near $1970 \mathrm{~s}$

397 extent, short vegetation grassland declined $\sim 5,930 \mathrm{~km}^{2}$, barren lands increased by $\sim 4,190 \mathrm{~km}^{2}$, and water

398 extent changed by $\sim 860 \mathrm{~km}^{2}$. The drought in 1988 is apparent in the reduction of agriculture extent in

399 the 1990 map and recovery in the 2000 map (Fig. 7, D, F and G).

400

No extensive changes in land use have been noted in this region and the land cover is primarily

401 composed of agriculture (corn, wheat, sorghum) and rangeland for cattle grazing. Large increases in

402 standing water (prairie potholes or sloughs) were observed in the Landsat record spanning from 1972-

4032000 . Previous fall precipitation has been found to account for $63 \%$ to $65 \%$ of the variation in the

404 number of wetland basins (Larson, 1995). Apparent dramatic increases in wetland size have been

405 recorded from increases in precipitation and may contribute to observed crop yield. Land cover change

406 does not appear to be the motivator for the observed change in vegetation dynamics in this region.

407 Climate impacting dry land agriculture produced the NDVI anomaly. 

period because of recovery (Trenberth et al., 1988; Winter \& Rosenberry, 1998). Increases in precipitation influenced dry-land crop production in this area by enhancing plant growth. Near infrared

411 reflectance was observed to increase with crop production in Landsat (Fig. 7, F and G). Corn production was noted to be highly variable and was limited by erratic precipitation patterns (USDA, 2006). Winter et al., (1998), have noted current conditions to be the wettest on record over the past 130 years, and

414 potentially the past 500 years. The responses of wetlands and agricultural lands to increased

415 precipitation was consistent with our observed NDVI anomalies.

\subsubsection{Crop Data}

To verify if abiotic changes were enhancing vegetation photosynthetic capacity, we investigated the NASS records. Sequential seasonal vegetation indices profiles revealed crop canopy emergence, maturation, and senescence. These measurements have been related to crop condition and yield (Benedetti \& Rossini, 1993; Boissard et al., 1993; Doraiswamy \& Cook, 1995; Labus et al., 2002; Rasmussen, 1992). Marked increases in wheat production have been noted, which we found impacted the NDVI.

Yields of wheat increased in three selected Northeastern Montana counties within the NDVI anomaly area. Acres of wheat production rose $>40 \%\left(>400 \mathrm{~km}^{2}\right)$, and a marked increase was noted after the 1988 drought (Fig. 7, E). Increases in yield were associated with the increased precipitation after the drought of 1988, returning crop production in this region to its normal state. Adjacent counties to the anomaly region were also investigated and they did not have a marked increase in production. The primary limiting factor to growth in this area was precipitation which increased substantially and caused 430 the observed NDVI anomaly. 


\subsection{High Plains}

The Oklahoma Panhandle study area is dominated by human land use of agriculture and pasture

land. A similar agro ecosystem to the Southern Saskatchewan/ Dakotas study region exists here. The landscape consists of flat to irregular plains where sedimentary bedrock is overlain by alluvial deposits.

436 The High Plains have a semi-arid environment where precipitation is the limiting climatic variable to

437 vegetation growth. Precipitation has been found to spatially and temporally modulate NDVI in Kansas

438 (Wang et al., 2001). Over the past 20 years, variations in crop type and production have varied

439 substantially. Although the spatial/temporal heterogeneity of crop type and production can possibly

440 cause the observed change in AVHRR NDVI, this semi arid region is heavily reliant on irrigation to

441 grow more productive crops. Irrigation practices and crop selection were found to explain the NDVI

442 anomalies observed (Fig. 8).

\section{3.4.1. Land Cover}

445 Marked changes in land cover were found in Northern Texas, Oklahoma, and Kansas. Landsat 446 analysis revealed changes in irrigation extent. $\sim 100,000 \mathrm{~km}^{2}$ was mapped and during observations 447 agriculture increased by $\sim 2,850 \mathrm{~km}^{2}$, short vegetation grassland declined $\sim 4,860 \mathrm{~km}^{2}$, barren lands 448 increased by $\sim 1,650 \mathrm{~km}^{2}$, and water extent changed by $\sim 160 \mathrm{~km}^{2}$. Center pivot agriculture expansion 449 was pervasive throughout this region (Fig. 8).

450 Expansion of irrigated agriculture is largely constrained by access to the Ogallala aquifer. Water 451 in this aquifer is considered a nonrenewable resource because it was formed from melt water from the 452 Rocky Mountains during the Pliestocene era. The High Plains aquifer in this region has experienced a $453>30 \%$ decline in ground water over the past 40 years (Scanlon et al., 2005). Standard practices consist 454 of dry land farming (completely reliant on rain) and furrow and dike irrigation (flooding fields). Using 
455 center pivot irrigation over previous irrigation practices has tripled production (biomass) and consumed

456 less water (Opie, 2000). Enhanced production was due to the center pivot's ability to more evenly and 457 accurately irrigate fields. Expansion of center pivot irrigation in this region from 1972-2000 was 458 marked and evident at the Landsat resolution (Fig. 8, F and G).

459 Abiotic variability did not impact vegetation in this region. Normal precipitation ranges $30-50$

$460 \mathrm{~cm}$ of rain a year, when a majority of the crops (corn, wheat and sorghum) require up to $76-101 \mathrm{~cm}$ (for

461 corn) during the growing season. The deficit of precipitation relative to evaporation ranges from $20-$

$462160 \mathrm{~cm}$ (Covich et al., 1997). Droughts are common in this area and tend to occur every 20 years and 463 can last between 5-10 years (Opie, 2000). The most severe drought occurred in the 1930's (Great Dust

464 bowl) and the second during the 1950's (Little Dust bowl). More recent droughts, although minor in 465 comparison, have occurred during the late 1970s, late 1980s and most recently in 1996 (Covich et al., 466 1997). The 1988 drought did not impact this region with the severity incurred in the north central

467 United States and parts of the North East (Trenberth et al., 1988). Dry spells do not impact the farmers 468 to the extent of previous years because of the development of the high plains aquifer irrigation networks, 469 which now extend for more than $16,000 \mathrm{~km}^{2}$ (www.hpwd.com). A heavy reliance on ground water has 470 been developed to offset the irregular patterns of precipitation.

\section{3.4.2. Crop Data}

473 To verify if abiotic changes were enhancing vegetation growth we examined the NASS records.

474 Alterations in crop production were noted in the agricultural data and a trend similar to the Dakota 475 region appeared to be the case. Substitution of corn for grain, the dominant crop of the region, showed 476 marked increases in production. From 1982 to 1997 in Dallam, Sherman, Hartley and Moore Counties 477 located within the AVHRR NDVI anomaly region centered on Dalhart, Texas corn production had 
478 increased $>\sim 200 \%$ (Fig. 8, E). Counties located outside of the anomaly region experienced little to no 479 growth in corn for grain production. NDVI seasonal profiles have been shown to aid in estimating crop 480 performance and the observed anomaly trends appear to reflect this observation (Benedetti \& Rossini, 481 1993; Boissard et al., 1993; Doraiswamy \& Cook, 1995; Labus et al., 2002; Rasmussen, 1992). This 482 positive growth relationship between crop statistics and enhanced NDVI signature was apparent in our 483 study.

484 Change from wheat to corn production appeared to be causing the marked increase in the 485 AVHRR NDVI. Conversion to center pivot irrigators for corn production enhanced the observed 486 AVHRR NDVI anomaly. Expansion of center pivot irrigated agriculture throughout this region had a 487 marked impact on land cover in this region and was visible in Landsat (Fig. 9). The coupled influence of 488 change in crop type and more extensive irrigation networks resulted in the AVHRR NDVI anomaly.

\subsection{Quebec}

The southern Quebec study region encompasses a majority of the southern portion of the province, which is mixed boreal forest. The ecotone is very similar to the Northern Saskatchewan as they are both considered to be a part of the North American Boreal Shield. Many of the same tree species also exist in this region and they have the same response and succesional sequences. Similar to Northern Saskatchewan, two species are very common: white spruce (P. glauca); and black spruce $(P$. marinana). Other species present include: eastern larch (L. laricina); balsam fir (A. balsamea); jack 497 pine ( $P$. banksiana); trembling aspen ( $P$. tremuloides); and paper birch (B. papyrifera). The observed AVHRR NDVI anomalies are around the Lac Saint-Jean area in the East to the Reservoir Gouin to the West (Fig. 10, A). This region has experienced extensive logging and modifications to the forest cover 
501 this region; large fire events have only been observed further to the North. Population density occurs

502 toward the East in the Saguenay Lac Saint-Jean region where over 300,000 inhabitants are distributed over 56 municipalities (Alma, 2006).

504

\subsubsection{Land Cover}

Land cover analysis for this region indicated marked changes in vegetation cover. $\sim 170,000 \mathrm{~km}^{2}$ were mapped, and during observations needle leaf evergreen forests declined by $\sim 2,350 \mathrm{~km}^{2}(-39 \%$ change in area), short vegetation grassland increased $\sim 1310 \mathrm{~km}^{2}(+37 \%$ change in area), broad leaf deciduous forests increased by $\sim 5,580 \mathrm{~km}^{2}(+15 \%$ change in area), and dwarf trees and shrubs extent changed by $\sim 2,570 \mathrm{~km}^{2}(+26 \%$ change in area) (Fig. 10). Logging and recovery from logging was

511 common throughout this region.

513 Service which both have recorded increasing rates of logging. Fire did not have a significant role in

514 disturbance regime in this region as it did in Saskatchewan. Extensive salvage logging was initiated by 515 a wide spread spruce budworm (C. fumiferana) outbreak during the mid 1970s. During the last century,

516 Eastern North American forests have suffered increasing rates of spruce budworm outbreaks rising to $517 \sim 550,000 \mathrm{~km}^{2}$ in 1975 (Kettela, 1983). Blias et al. (1981; 1983), reported that a spruce budworm 518 outbreak collapsed in 1975 in Southern Quebec, and extensive mortality up to $91 \%$ of balsam fir ( $A$.

519 balsamea), their preferred fare, occurred. Recovery of the understory was reported to be rapid of tree 520 species that comprised the original stand because they did not suffer extensive infestation. This has 521 been interpreted to be part of the successional system (Baskerville, 1975; Blias, 1985). The Canadian 522 forest service permitted extensive salvage logging to take place as much of this region is utilized for 523 cash crops in pulp and paper production. We observed in Landsat data that recovering vegetation at 
524 logged sites had an enhanced near infrared reflectance that would also enhance the AVHRR NDVI (Fig.

$525 \quad 10, \mathrm{E}, \mathrm{F}$ and G).

526

527 3.5.3. Logging Rates

528 The Canadian Forest Service has reported substantial increases in logging rates throughout the

529 province of Quebec. Total annual harvesting during the NDVI record has grown from 2,000 $\mathrm{km}^{2}$ a year

530 to $>3,500 \mathrm{~km}^{2}$. It has been reported by Sabol et al., (2002), that post-logging regrowth in Pacific

531 Northwest U.S. conifer forests had a higher NDVI after 3-4 years than the mature conifer stands they

532 replaced, which persisted for 10 to 30 years. We observed higher near infrared reflectance in Quebec at

533 disturbed sites, which increased NDVI. Forest age structures as suggested by Casperson et al., (2000),

534 may be responsible for the observed trend increase in this region. The successional process of $P$.

535 glauca, which are ubiquitous in this region, begins after logging with fast growing deciduous species.

536 These deciduous species of paper birch (B. papyrifera) and trembling aspen (P. tremuloides) typically

537 have a higher NDVI signature than the conifers that replace them. In this region regrowth following

538 logging acts as a disturbance-driving element of the observed AVHRR NDVI anomaly.

540 3.6. Newfoundland and Labrador

541 The island of Newfoundland and the Labrador coast has a unique environment with a maritime

542 boreal forest influenced by the confluence of two ocean currents, the cold Labrador and the warm Gulf

543 Stream. Its maritime climate can change drastically depending on what current is dominating flow. The

544 entire island over $100,000 \mathrm{~km}^{2}$ has recorded a marked increase in NDVI over the 1992-1999 period.

545 Land use change is not a dominant factor in this region as it is sparsely populated and does not have

546 productive soil for agriculture. Over half of the population resides in St. Johns, the capital of 
547 Newfoundland on the eastern coast. Newfoundland also has a fairly extensive logging operation in the

548 West where large amounts of spruce and pine are harvested for pulp and paper production. The ecotone

549 is very similar to that of the Quebec study region. The vegetation of Newfoundland consists of dense

550 mixed forest of trembling aspen (P. tremuloides), paper birch (B. papyrifera), white spruce $(P$. glauca)

551 and black spruce (P. marinana) in the west. The central and eastern portions of the island are open

552 lichen woodland where fertile soils have been removed and underlying rock has been exposed by

553 ancient glaciers of the past (Fig. 11).

\subsubsection{Land Cover}

Extensive logging was noted on the western coast of Newfoundland for pulp and paper

557 production. From 1982 to 1999 an additional $100 \mathrm{~km}^{2}$ were logged but this is insignificant compared to 558 the $100,000-\mathrm{km}^{2}$ extent of the island (http://pndf.ccmf.org). Land cover results for this region indicate 559 moderate changes in vegetation cover. $\sim 170,000 \mathrm{~km}^{2}$ were mapped including Labrador, and during 560 observations needleleaf evergreen forests declined by $\sim 6,650 \mathrm{~km}^{2}(-10 \%$ change in cover type), short vegetation grassland increased $\sim 3,920 \mathrm{~km}^{2}$ ( $+7 \%$ change in cover type), broadleaf deciduous forests increased by $\sim 350 \mathrm{~km}^{2}\left(+12 \%\right.$ change in cover type), and barren extent changed by $\sim 1,360 \mathrm{~km}^{2}(+20 \%$

563 change in cover type) (Fig. 11, C). Logging and recovery from logging is pervasive throughout the 564 western portion of Newfoundland.

565 No other large-scale land cover trend was observed, as population density is sparse throughout 566 the region. Emergence of more deciduous species of paper birch (B. papyrifera), and trembling aspen 567 (P. tremuloides) in formally logged areas was noted from aerial over flights. However, these alterations 568 in land cover are insignificant compared to the observed NDVI anomaly, which extends over the entire 569 island. Land cover land use change is not a major factor in the observed NDVI trend; abiotic factors are 
570 the dominant cause. Annual surface temperature nearly doubled over the 1990's and it appears to have

571 enhanced the NDVI record. The growing season has extended by 17 days and enabled more biomass to

572 be produced (Fig. 11, F). These marked climate changes over one decade have been reflected in the

573 NDVI record as anomalies. The intense change in surface temperature is responsible for the observed 574 anomaly in NDVI (Neigh et al., 2007).

575 Newfoundland has temperature-constrained environment where precipitation is non-limiting.

576 Muskegs are a common feature in the landscape held by ancient glacial rock and rejuvenated by frequent

577 precipitation events. The climate of Newfoundland varies drastically because of its northern maritime

578 exposure on all fronts. During the last decade, the Gulf Stream has dominated the Labrador Current

579 allowing warm waters to reach Newfoundland's shores (Afanasyev et al., 2001). These warm currents

580 are driving an observed increase of $3.5^{\circ} \mathrm{C}$ in 1992 to $7^{\circ} \mathrm{C}$ in 1999 in mean annual temperature (Fig. 11, $581 \quad \mathrm{E})$.

582 A typical warm weather promotes growth and photosynthesis in this mixed boreal forest. The 583 growing season has extended by over 17 days from 1982 to 1999, reducing snow cover and enabling 584 more vegetation productivity (Neigh et al., 2007). Similar to the northern Saskatchewan study region, 585 growth is often limited in coniferous forest by mineral poor soils with productivity controlled by nutrient 586 cycling through litter fall and decomposition (Cole \& Rapp, 1981). Enhanced temperature accelerates 587 decomposition enabling more nutrients to be released into the soil (vanCleve et al., 1983). Culminating 588 with this fact, black spruce (P. mariana), the dominant stand species in this region, has an optimum 589 temperature for photosynthesis of $15^{\circ} \mathrm{C}$, with a $90 \%$ rate maintained between $9^{\circ} \mathrm{C}$ and $23^{\circ} \mathrm{C}$ (Vowinckel 590 et al., 1975). Warmer temperatures reduced snow cover and extended growing season length. An in 591 depth quantitative analysis of climate influenced vegetation productivity is beyond the scope of this 
paper; the role of increasing temperature to vegetation productivity will be investigated with simulation

593 modeling in the future.

594

4. Synthesis

Six different areas displaying marked changes in NDVI values for the period from 1982 to the

\section{7} present have been examined using multi-temporal Landsat data and other ancillary data sources to provide attribution for the changes. These results indicate a complex interaction between anthropogenic changes and direct biophysical impacts. In some areas, especially in northern latitudes, the changes appear to be the result solely of biophysical impacts. In the Mackenzie Delta it appears that temperature increases are the prime drivers. In Newfoundland the immediate cause of increases in NDVI appears to be related to regional increases in water temperatures in the adjacent ocean. In contrast in northern Saskatchewan the proximate driver of increases in NDVI is forest regrowth following frequent large forest fires, though the latter may be affected by temperature increases associated with global warming superimposed on cyclical fluctuations in fire frequency.

In the other examined areas the impact of anthropogenic influences was more direct. In Quebec the anomalies arise from the regeneration of extensive logged areas of evergreen forests leading to 608 forests dominated by deciduous species. In southern Saskatchewan and the Dakotas the increases in NDVI derive from increased agricultural activity following the increased precipitation rainfall after an 610 extensive drought prior to 1992. But further south in the High Plains of the Oklahoma Panhandle, the 611 area's increases in NDVI are related to large increases in pivot irrigation relying on ground water. The pattern of NDVI anomalies over the time period considered therefore arises from a variety

613 of interacting factors. Some of these changes appear to be driven by long-term climate change but most 614 appear associated with climate variability on decadal and shorter time scales along with direct 
615 anthropogenic land cover conversions. Interactions between the three types of drivers of change

616 demonstrate the difficulty of interpreting changes in NDVI. Furthermore this indicates the complex

617 nature of changes in the carbon cycle within North America. Coarse scale analysis of changes could

618 well fail to identify the important local scale drivers controlling the carbon cycle and to identify the

619 relative roles of disturbance and climate change.

620

\section{5. Conclusion}

622 North American vegetation dynamics driven by a number of different biophysical phenomena

623 have been revealed in this research. Discrete events over the past two decades have induced change in 624 ecosystem functioning that have been identified with multi-resolution satellite imagery. We find that:

625 (1) Multi-resolution data provides information critical to the state of knowledge of vegetation dynamics

626 in North America; (2) land cover land use change driven by humans had a marked impact to North

627 American photosynthetic capacity; (3) natural abiotic and anthropogenic events can modify vegetation

628 dynamics in concert or singularly; (4) coupled processing of multi-resolution data can be performed

629 efficiently to extract synoptic information of ecosystem state; and (5) information about vegetation

630 dynamics enhances ecosystem models to emulate altered terrestrial biogeochemistry and land surface

631 energy exchange.

632 Investigation through multi-scalar and multi-temporal data revealed land cover dynamics during

633 the 1980s and 1990s. In correspondence to Hicke et al., (2002), Neigh et al., (2007), and Zhou et al.,

634 (2001), changes in temperature and precipitation have also been found to be marked contributors to

635 vegetation change. Human activities were observed to have an impact to vegetation productivity

636 altering the relationship between the biota and the physical environment. The unique contribution of this

637 study is how regional land cover land use change altered vegetation dynamics at the continental scale in 
638 North America. Continued investigation is needed to extrapolate how natural and anthropogenic

639 changes impact the North American carbon cycle. Future work will investigate areas of large-scale

640 NDVI decreases within the 1982 to 2005 period of our study.

641

642 Acknowledgements

643 This research was funded by the National Aeronautics and Space Administration, North

644 American Carbon Program grant NRA-04-OES-01. We would like to thank Dan Slayback, for

645 assistance in data preparation. 

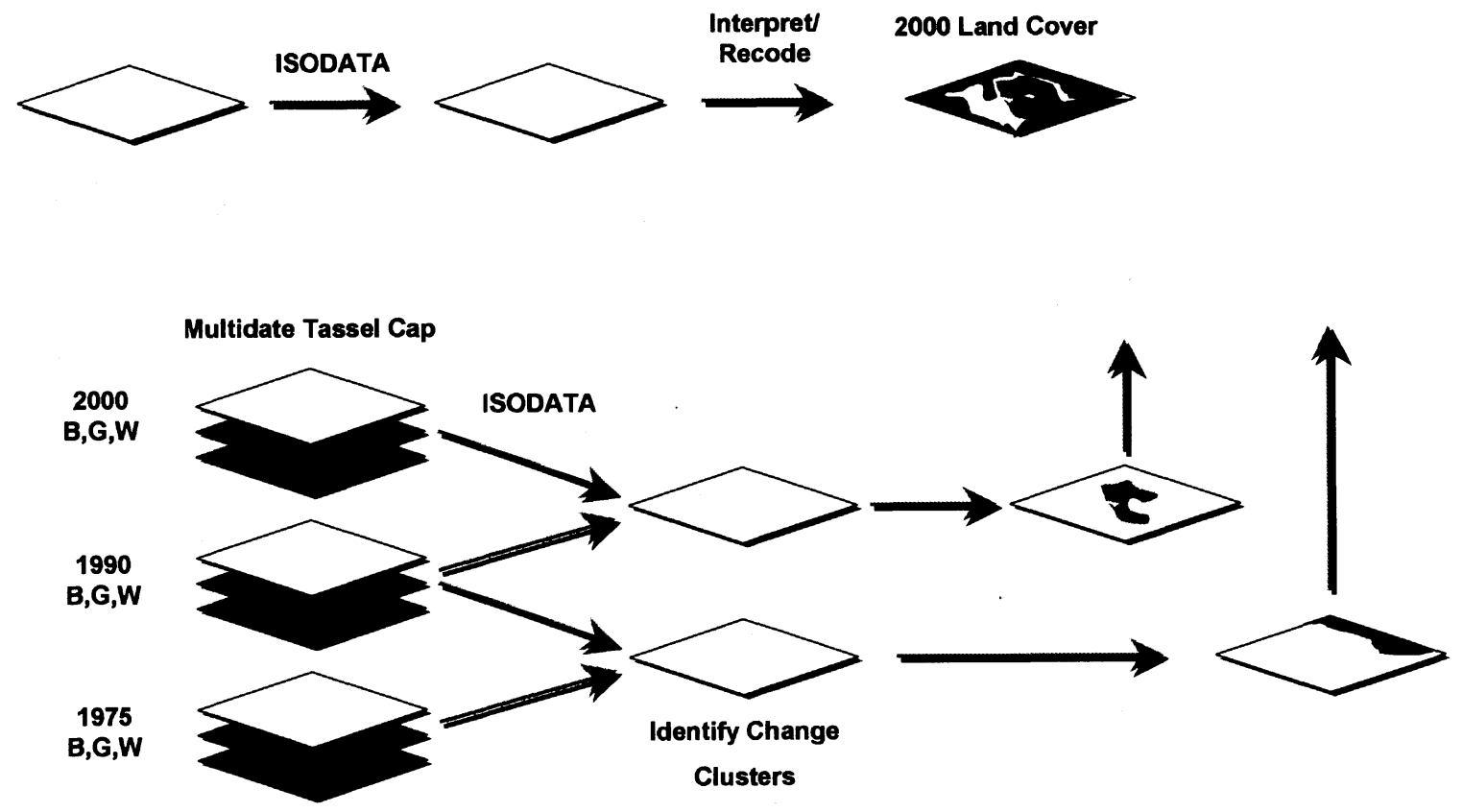

Fig. 1. Diagrammatic representation of the land cover classification method developed to extract thematic information from multi-temporal Landsat data. Channels 3,4 and 5 from Landsat-7 were first processed in an unsupervised method into $\sim 50$ classes that subsequently were aggregated into the 9 International Geosphere Biosphere Program land cover types.

Subsequently, all reflective channels were used to produce a multi-date "tassel cap" transformation for each time period and then subjected to an unsupervised aggregation to produce areas of change for each of the three time periods. The three time periods were then compared to identify changes from 2000 to 1990 and 1990 to 1970 s, respectively. This approach was used in the Mackenzie River delta, Northern Saskatchewan, Southern Quebec, and Newfoundland study areas. 

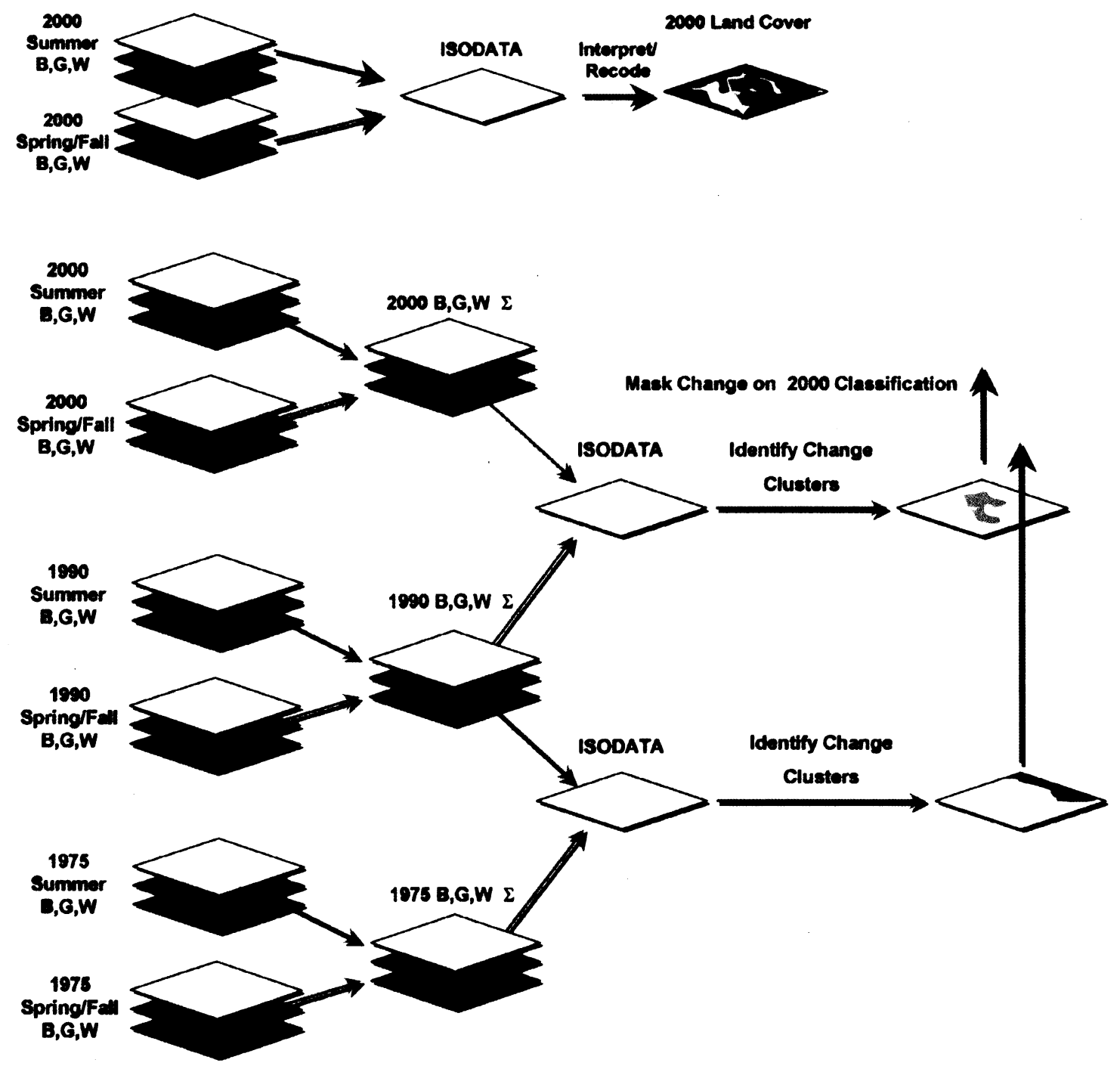

Fig. 2. Land cover change classification algorithm diagramming steps to extract thematic data from Landsat data for the Southern Saskatchewan and Oklahoma "Panhandle" agricultural study areas. Method two was adapted for regions with irrigated agriculture to capture inter annual variability in crop productivity. Performing a transformation on multi-date tassel cap images captures active irrigated agriculture and distinguishes between fallow agriculture and native grasslands. 
A

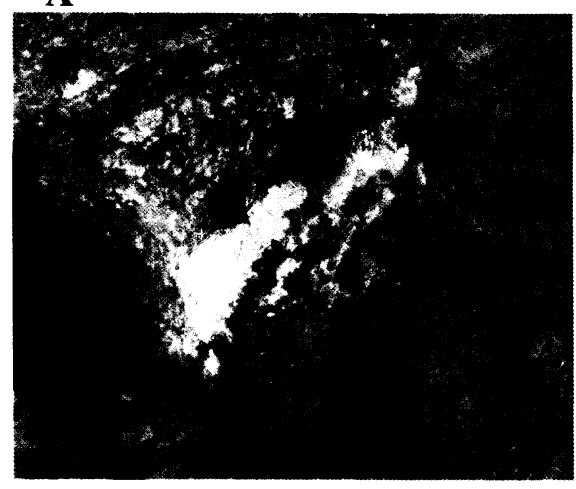

B

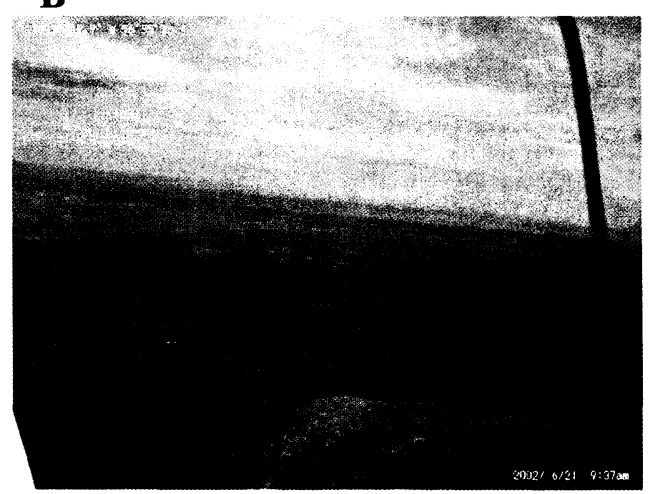

C

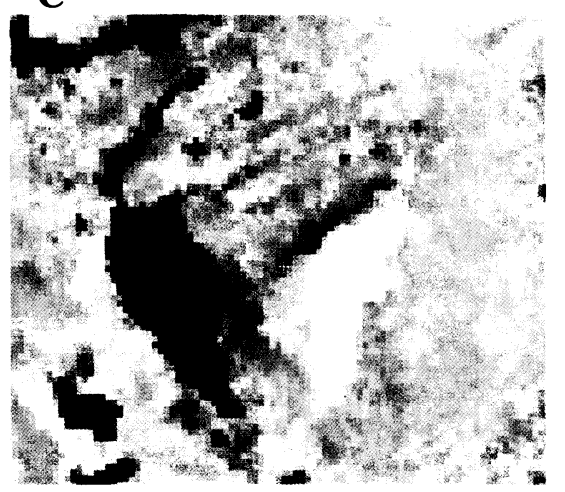

Fig. 3. An example of our validation efforts from Newfoundland. (A) A black and white geo-referenced digital air photo was obtained from the Canadian Government (id A26784_21, 8/03/1985). (B) A low altitude oblique aerial photograph taken by the authors with the GPS coordinates of the location of the camera. (C) A Landsat multi-spectral image using bands 4,5 , and 3 to represent red, green, and blue colors, respectively (path 4 row 26, 8/05/2001). The same geographic features, mountains and water bodies, were found to be useful for merging these types of data from North America study regions. 


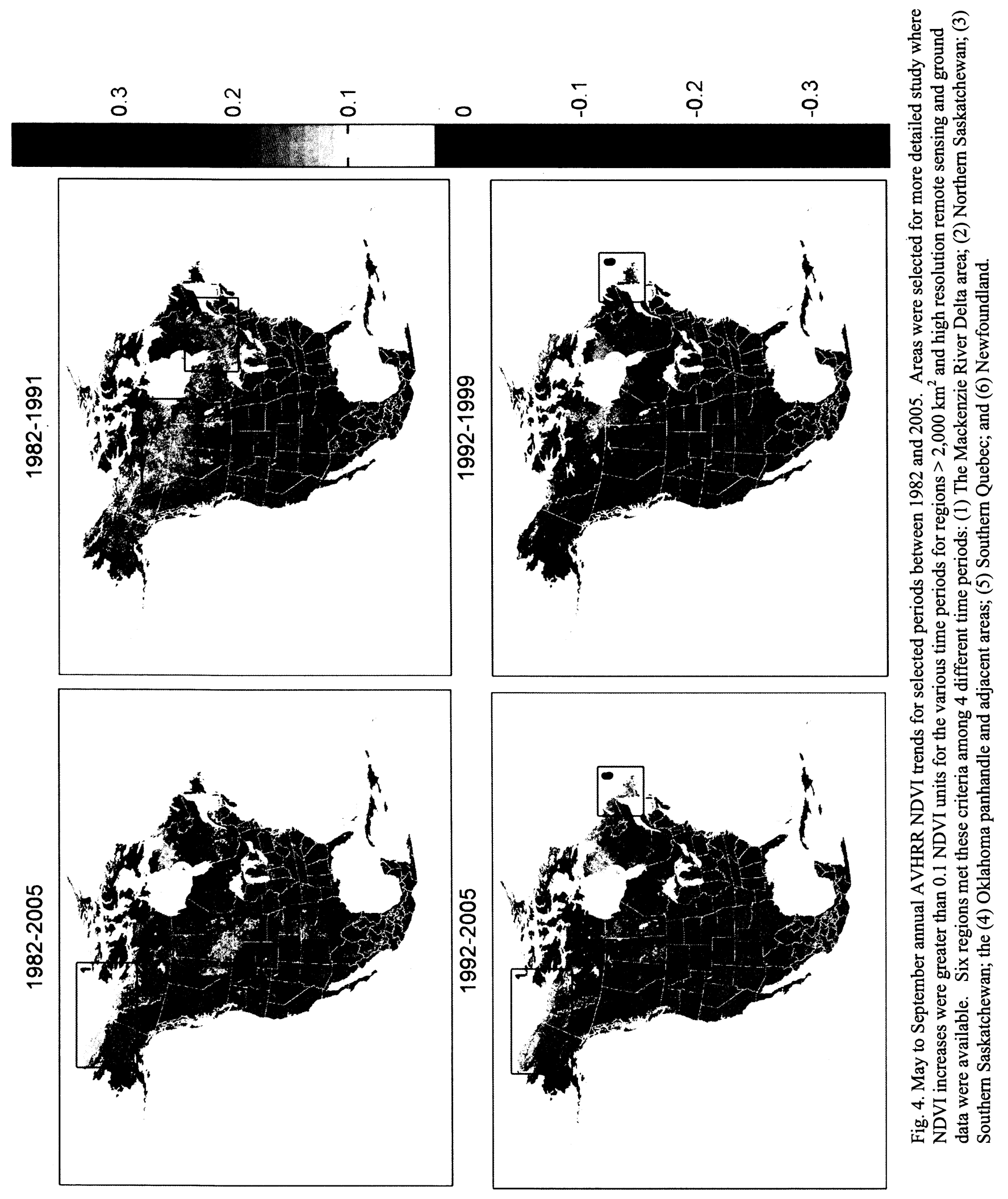


A

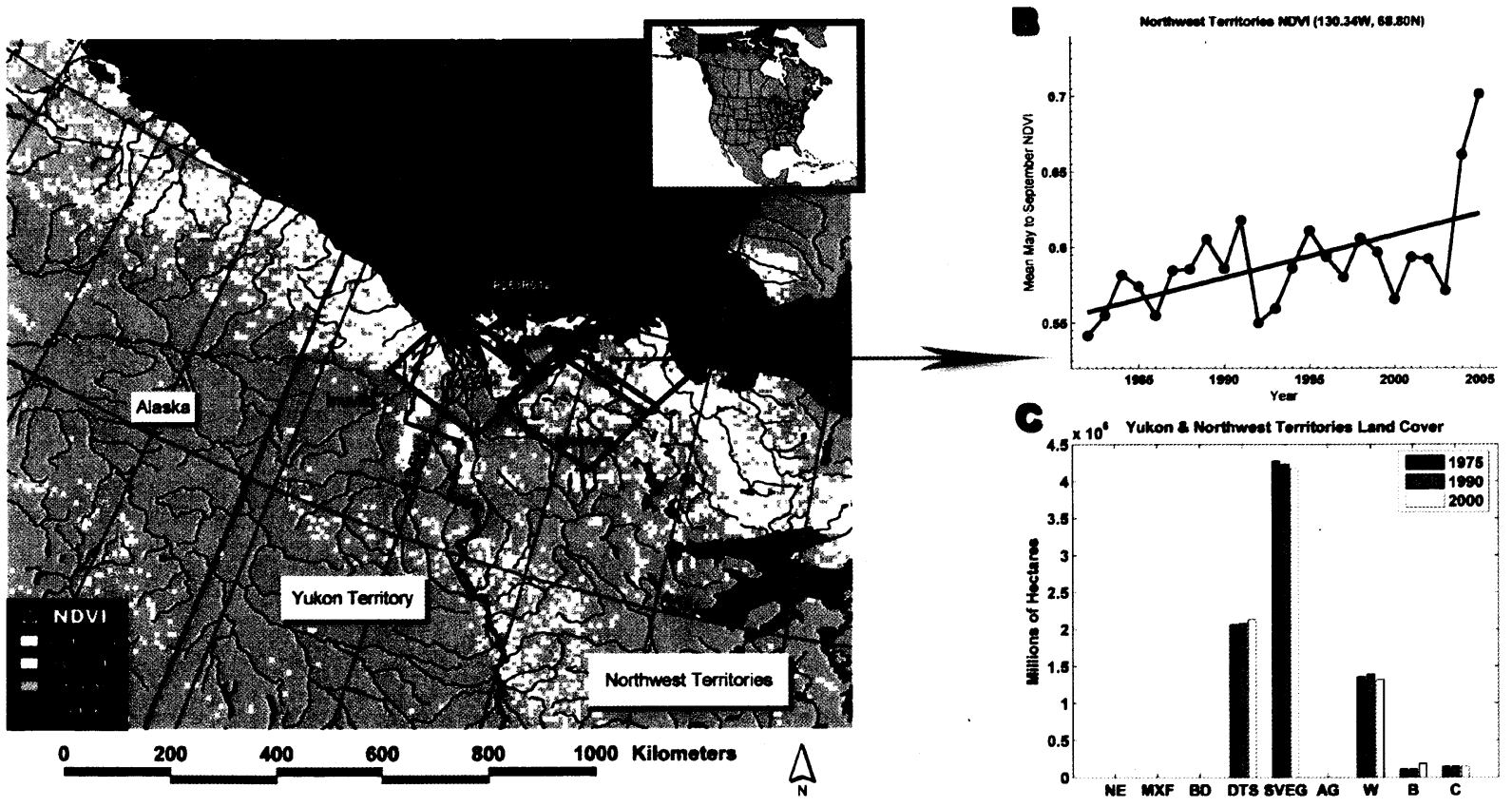

D

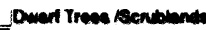

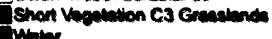

Barrenemen soilluben

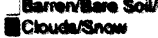
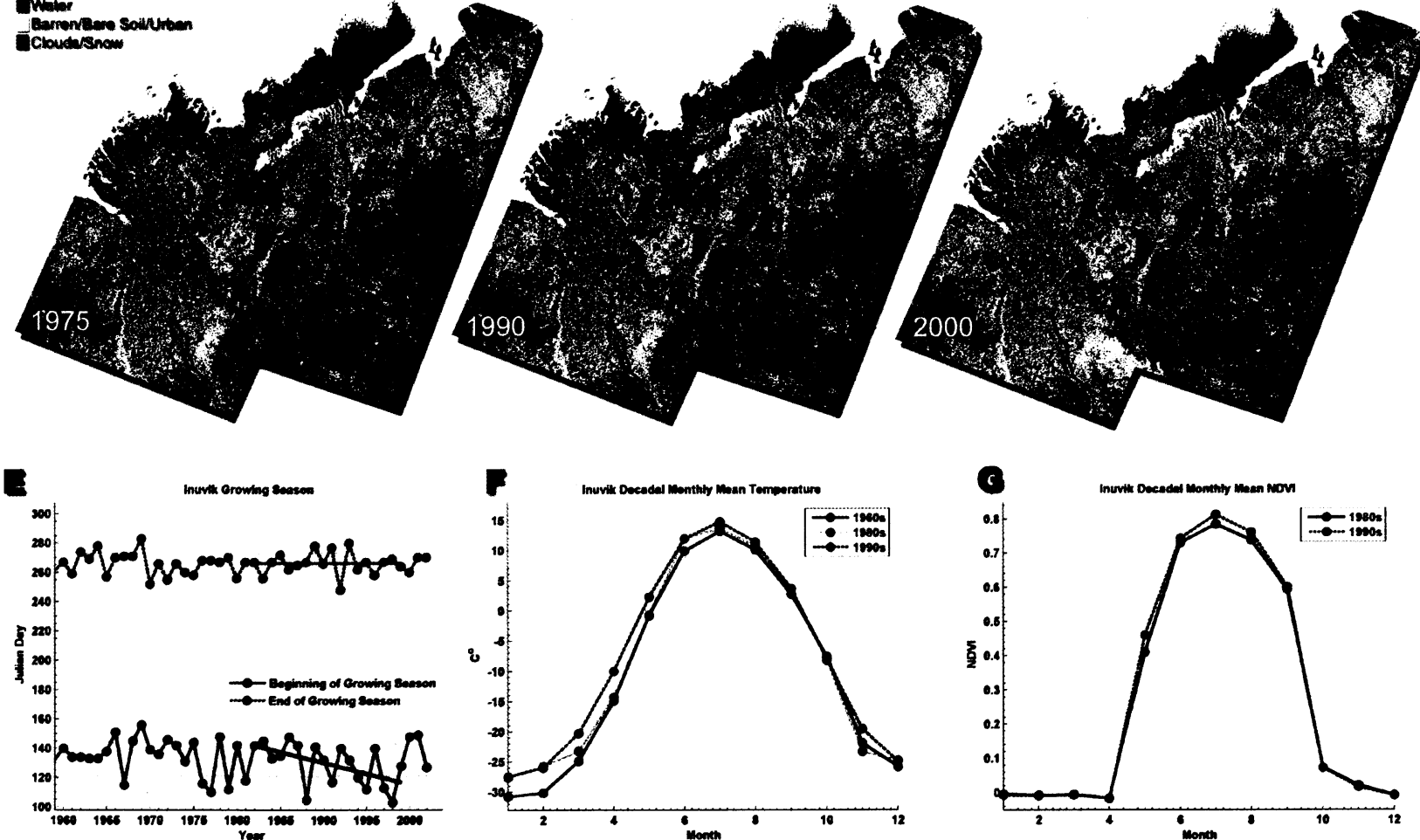

Fig. 5. A diagrammatic representation of the Yukon and Northwest Territories study area identified in Fig. 4. (A) Shows the Landsat scenes we have used in our study, (B) shows the NDVI time series for the area indicated by the arrow from Fig. 4, (C) shows the changes in the IGBP land cover classes for dwarf trees and shrub lands, short vegetation grasslands, water extent, cloud cover, and barren lands determined from the 1970s, 1990, and 2000 Landsat image, (D) shows the actual Landsat data for the three periods after the tasseled cap transformation was performed, (E) shows the change in growing season length from 1960 to 2002, (F) shows the increase in monthly mean temperature calculated by decade for the 1960s, 1980s and 1990s; and (G) shows the increase in monthly mean NDVI calculated by decade for 1980s, and 1990s. NDVI increase in this area (G) resulted from a longer growing season (E) due to increase surface air temperature $(\mathrm{F})$. 

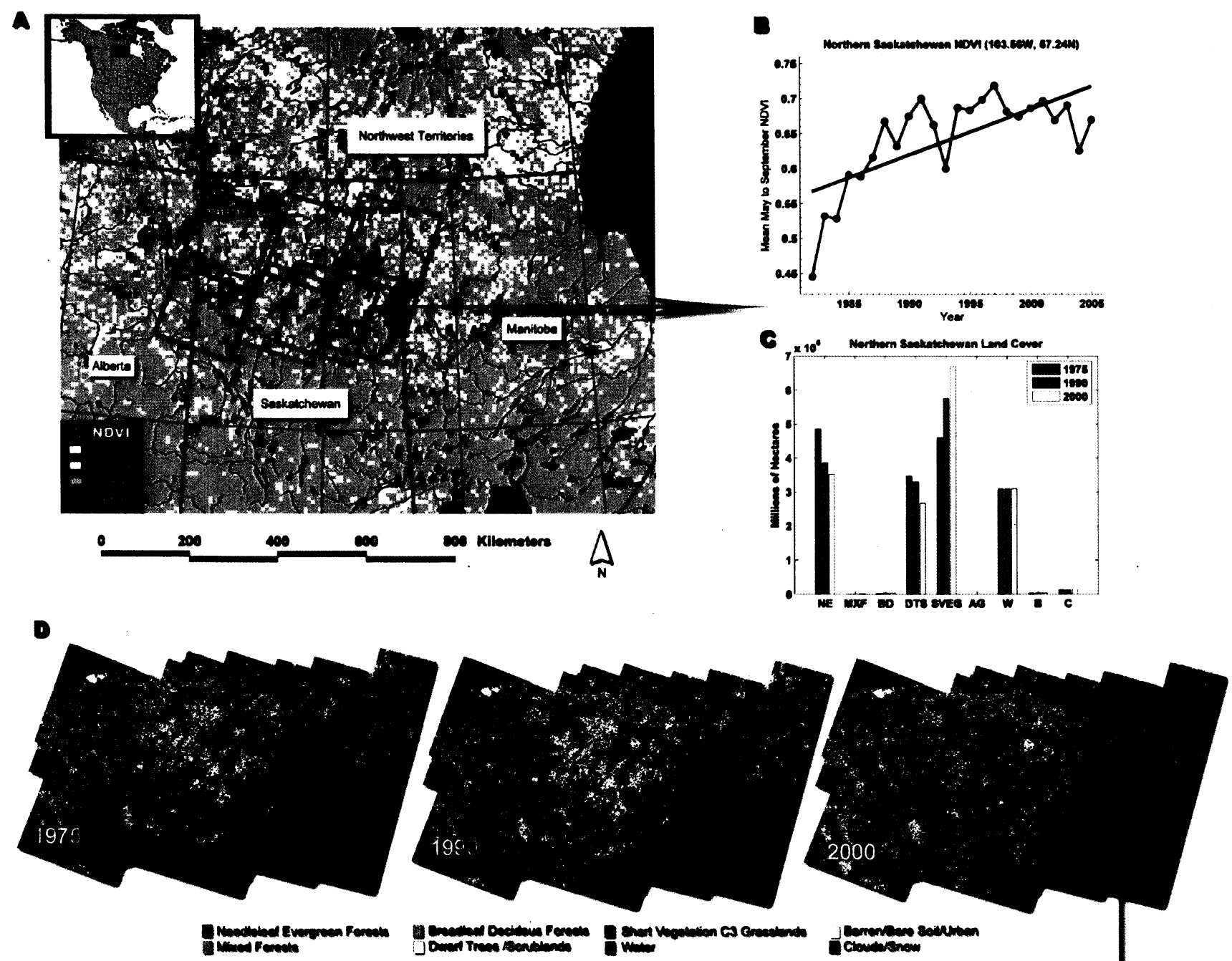

p37r20 TM 8/30/87 4,5,3 RGB
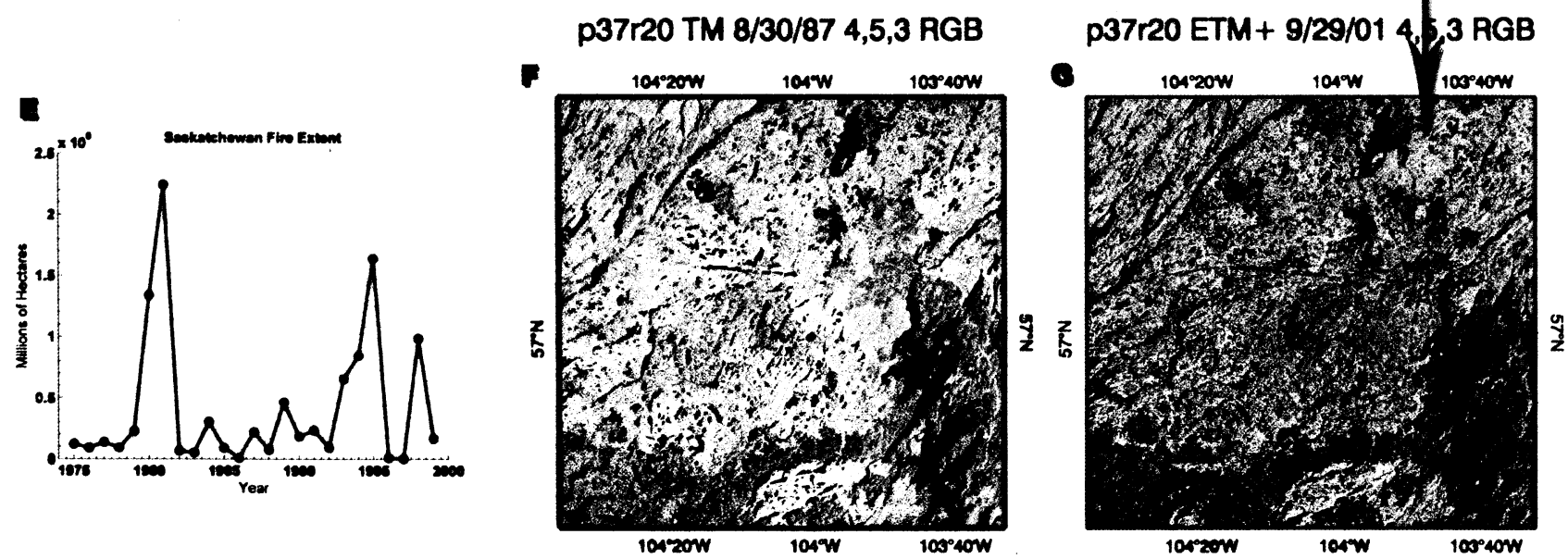

Fig. 6. The Northern Saskatchewan study area is identified in (A) with the Landsat scene areas superimposed upon the map. (B) Shows the NDVI time series while (C) shows how the 3 images have changed between the 1970s and 1990 and 1990 to 2000 time periods, respectively. (D) Is a representation of the Landsat data for the three periods using a tasseled cap transformation and (E) shows the fire frequency by year. ( $F$ and $G$ ) are the unprocessed data for one Landsat scene showing the areas that were affected by fire from locations indicated by arrows from (A to B) and (D to G). With the exception of 1980-1981 and 1995, fire was not a widespread phenomenon in this region. NDVI increase in this area resulted from fire in 1980, 1981 and 1995. 

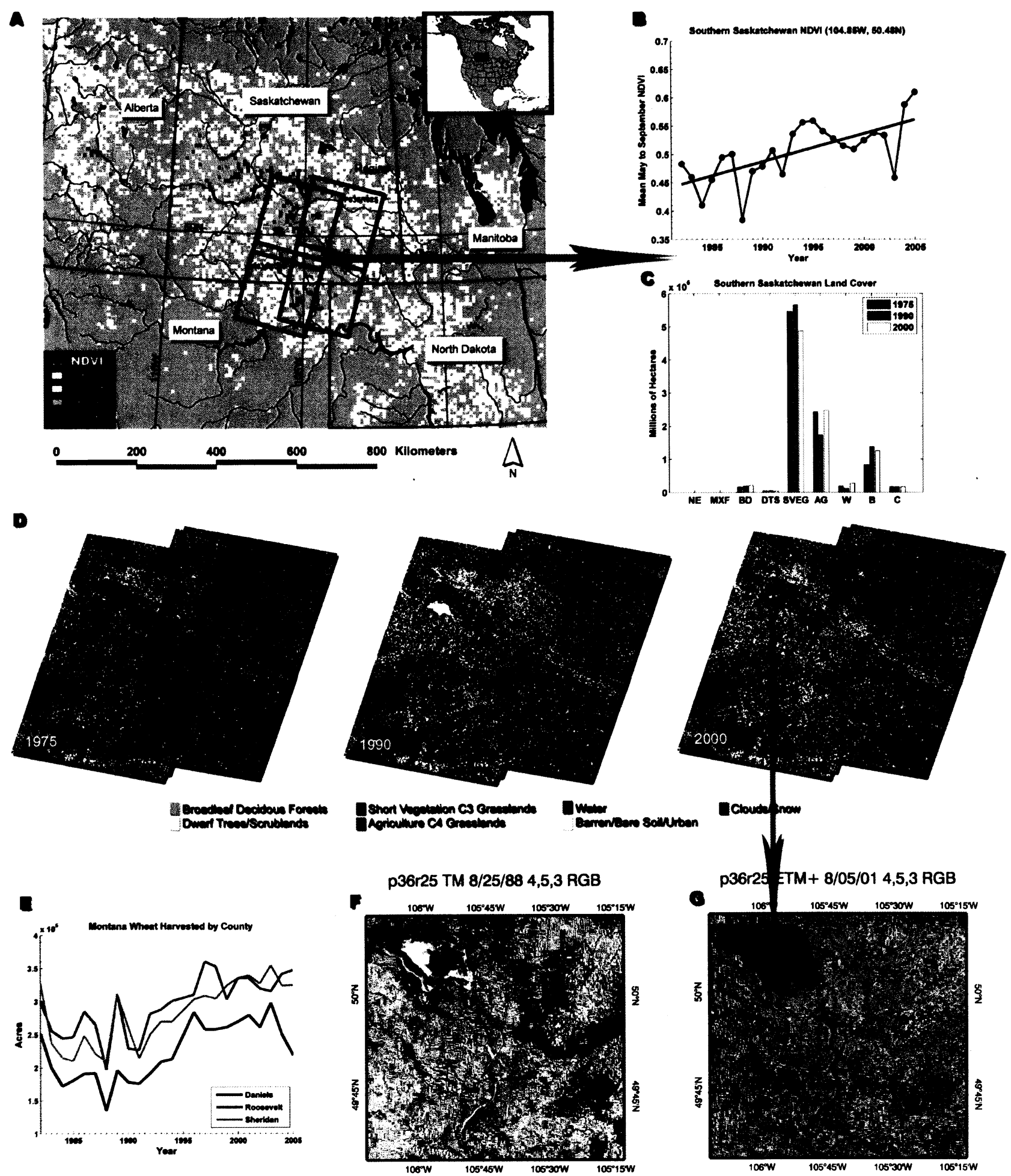

Fig. 7. The area in Southern Saskatchewan identified in Fig. 4 as having experienced a marked NDVI increase from 1982 to 2005. Superimposed upon (A) an image showing the areas of 1982 to 2005 NDVI increase are the 4 Landsat scenes used to investigate higher spatial resolution land cover and land use changes. (B) Shows the NDVI trends with time for the area represented by the arrow, (C) shows the changes in land cover for the three Landsat time periods, (D) shows the classified areas from the three GeoCover time periods, $(\mathrm{F})$ is a Landsat scene near the peak of the drought period, $(\mathrm{G})$ is a Landsat image during the period of recovery from drought, and $(\mathrm{E})$ is a plot of total wheat yield by year for the areas in Montana covered by Landsat data in Fig. 7a. The areas indicated in this figure exhibited NDVI trends because of increasing precipitation. 
A
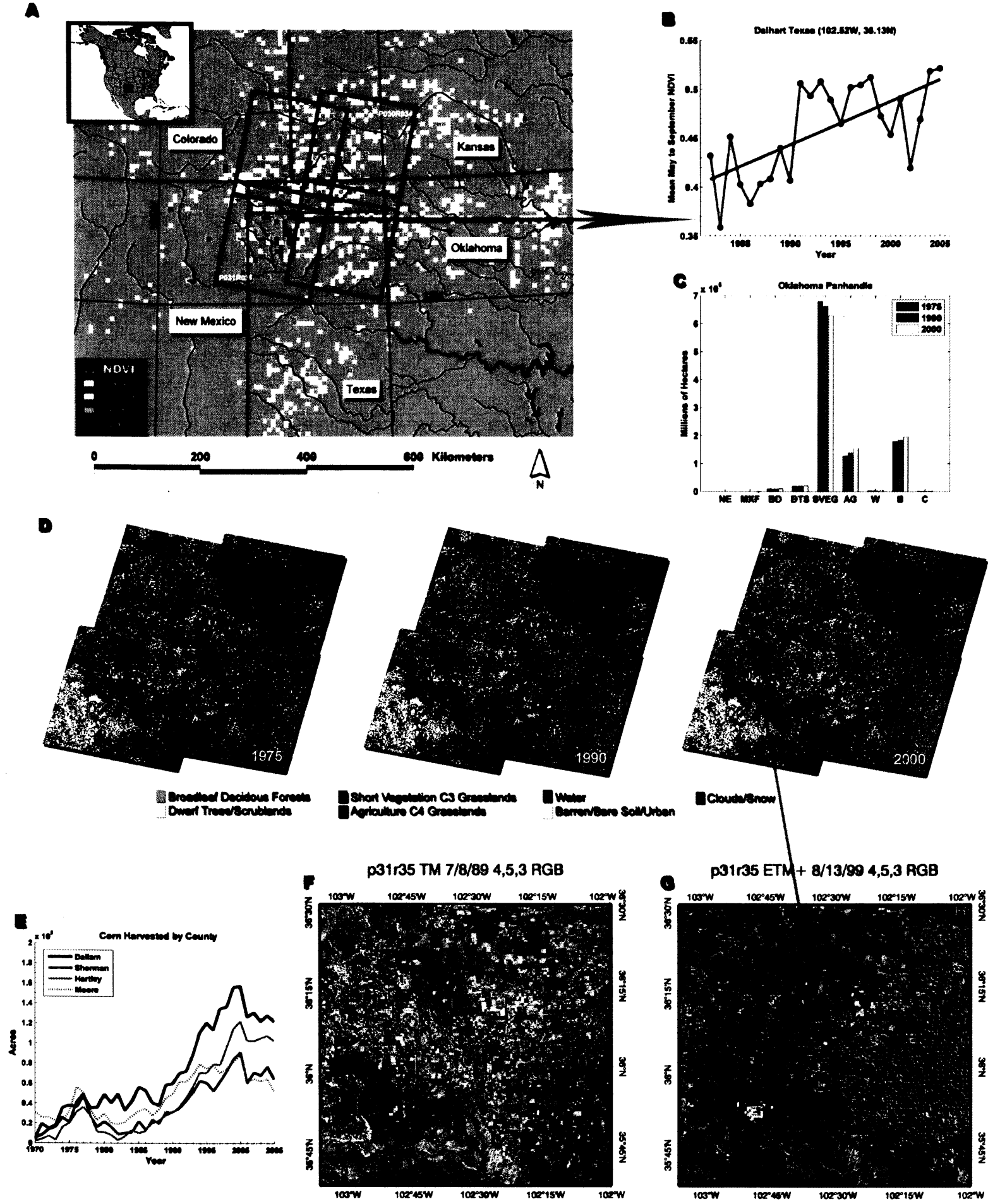

Fig. 8. An area of expanded irrigated agriculture in the "Panhandle" area of Colorado, Kansas, New Mexico, Oklahoma, and Texas that was identified in Fig. 4 as having experienced a marked NDVI increase from 1982 to 2005. (A) Is a diagrammatic representation of the areas of NDVI increase from 1982 to 2005 with an overlay of the 4 Landsat scenes used for the detailed spatial analyses, (B) is the 1982 to 2005 NDVI trend with time for the area indicated by the arrow, (C) shows the decrease in natural vegetation to irrigated agriculture over the 1970 s to 2000 time period, (D) shows the isoclustered Landsat data for the three time periods using two dates per time period, (E) are data of corn harvested by county from 1970 to 2005 , (F) is an unprocessed Landsat image from 1989 and (G) from 1999. Landsat area (F and $G$ ) is from arrow indicated from (A to $B)$. Note the expansion of center-pivot irrigated agriculture from 1989 to 1999, the increasing NDVI, and the increasing corn yields over the same time period in this semi-arid area. 


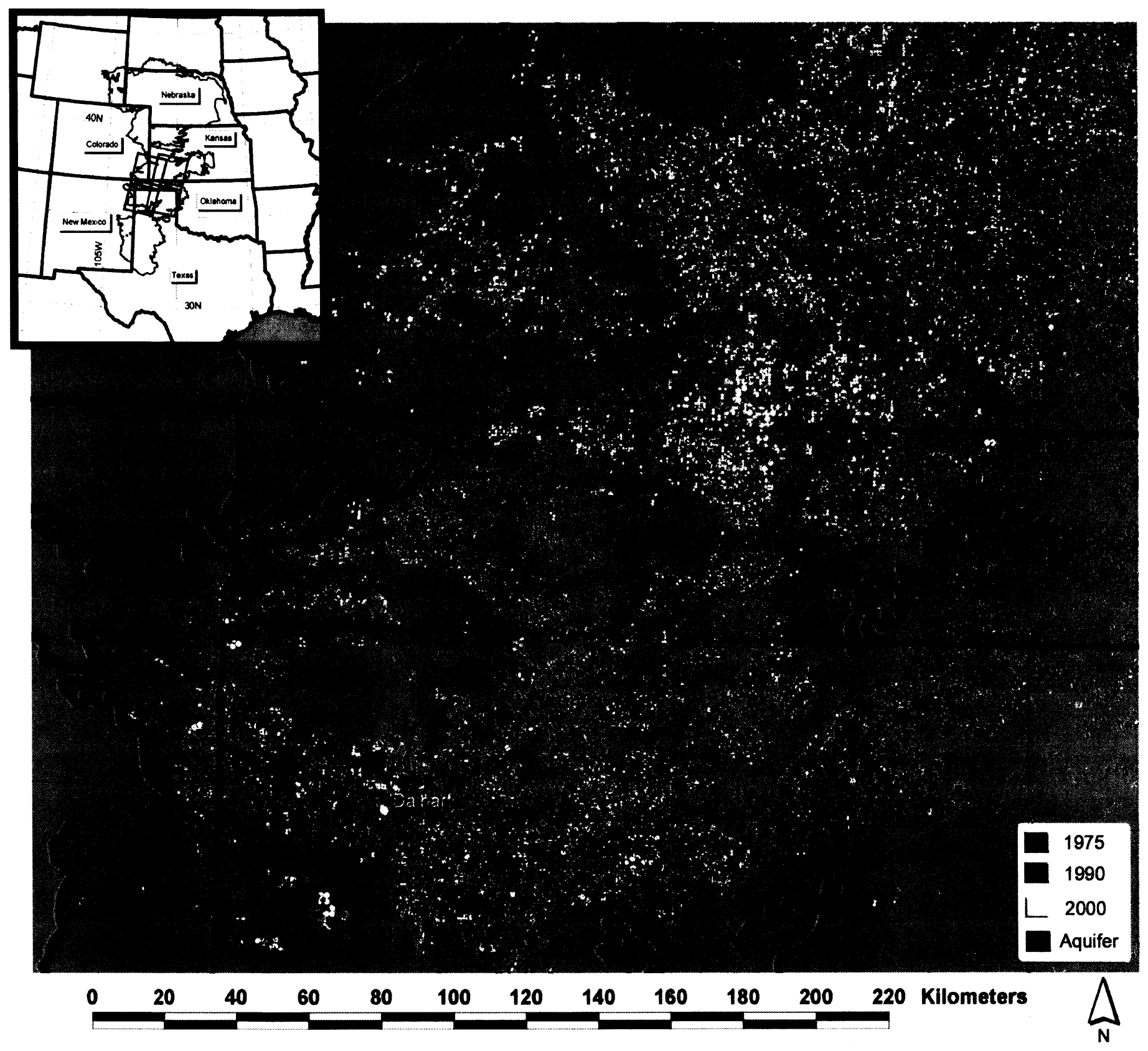

Fig. 9. A land cover classification of the Oklahoma "Panhandle" and adjacent areas, that shows the expansion of irrigated agriculture in this area from 1975 to 2000 based upon the analyses of Landsat data for these 3 time periods. Brown indicates agriculture land in 1975; red represents expansion in 1990, and yellow in 2000. Blue polygons represent the bounds of the Ogallala Aquifer. Our investigation of Landsat time series revealed expansion of agriculture land within the bounds of the Ogallala Aquifer; this change in agriculture extent and intensity coincides with the trend in AVHRR NDVI. 
$\Delta$
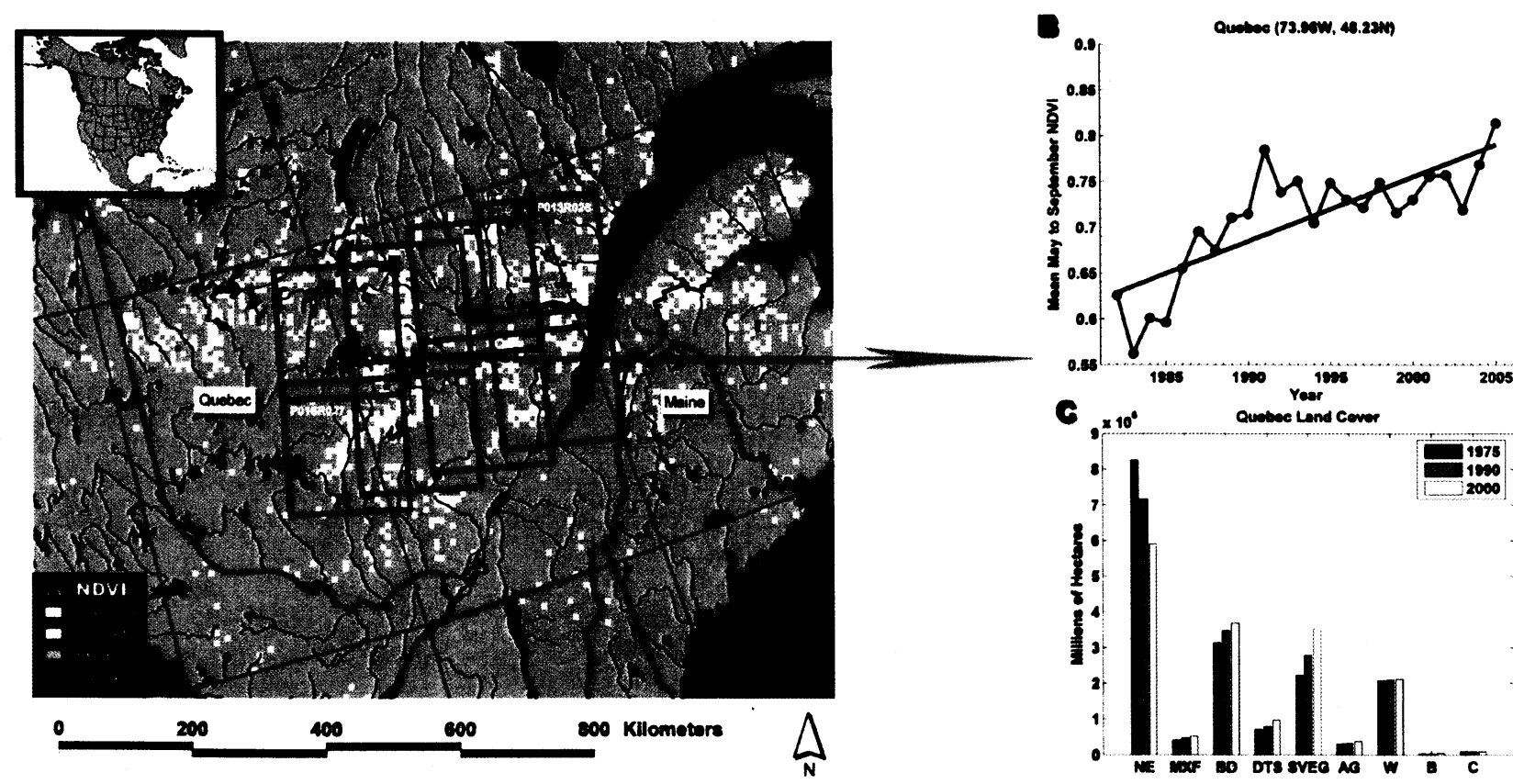

6

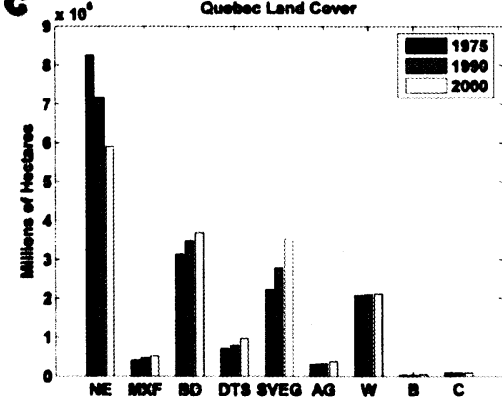

D
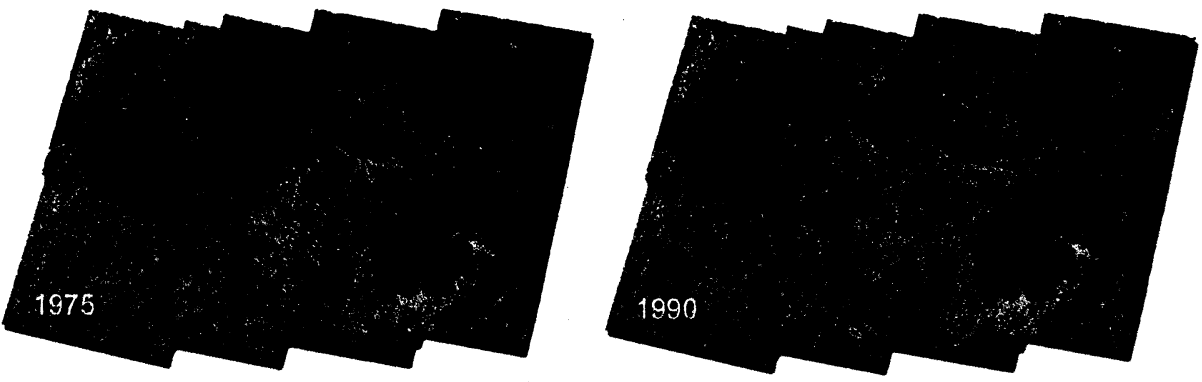

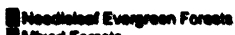

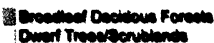
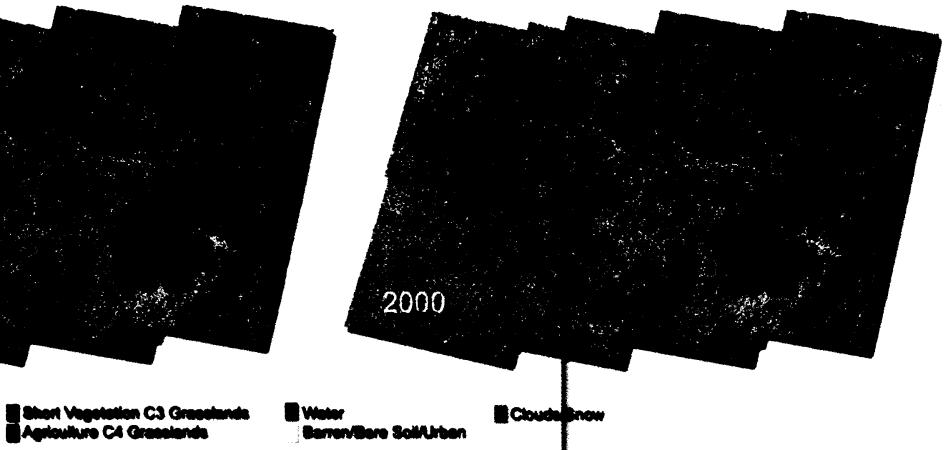

p16r26 MSS 9/23/72 3,2,1 RGB

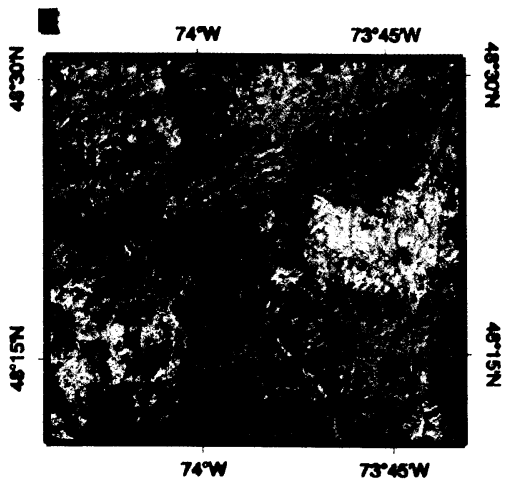

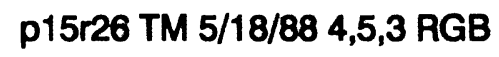

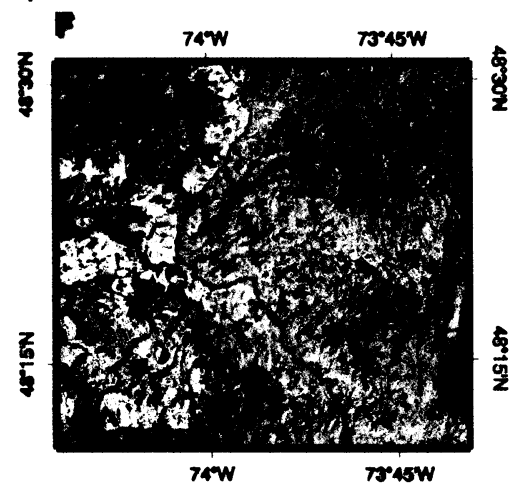

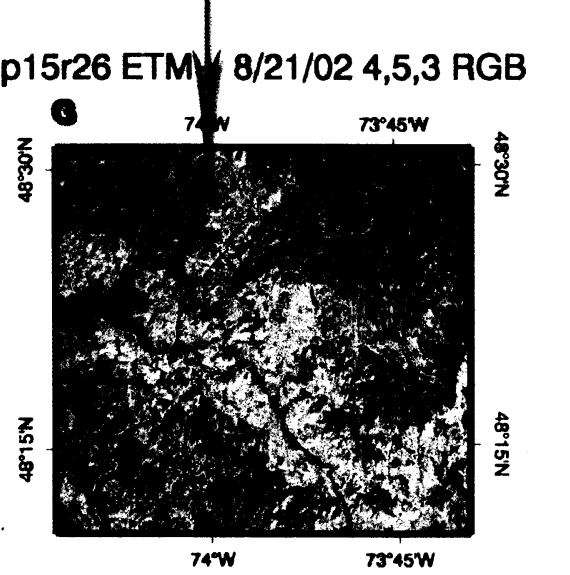

Fig. 10. (A) An area in southern Quebec that was identified in Fig. 4 has been extensively logged. (B) Shows the NDVI over time for the May to September time periods, (C) show the changes in land cover and land use associated with the logging, (D) shows the actual isoclustered Landsat data used for the 3 time periods. (E), (F), and (G) are the unclassified Landsat images from the 1972, 1988, and 2002 time periods, respectively. Landsat areas coincide with arrow from (A to B) where AVHRR NDVI increased from 1982 to 2005 (B). Note the decrease in NDVI in 1982-1983 due to logging/desiccation of forest from insects and the subsequent increase in NDVI as recovery and regeneration progressed. 


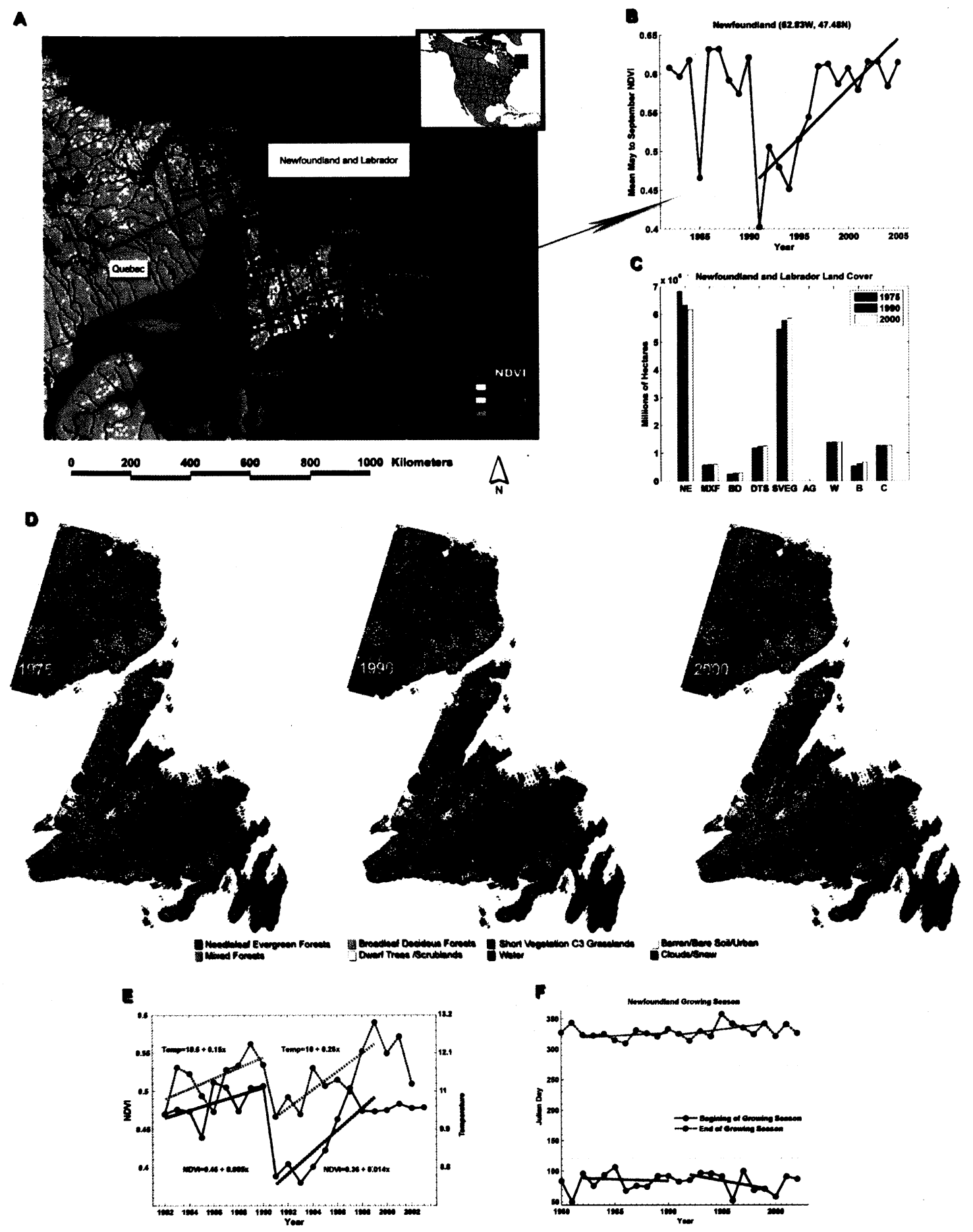

Fig. 11. The Newfoundland and Labrador areas that experienced marked increases in NDVI from 1992 to 1999 are noted in (A) with the Landsat images used for spatial understanding superimposed as an overlay. (B) The NDVI trend with time from 1982 to 2005 that shows a marked drop in NDVI in 1991 followed by a recovery from 1992 to the present. (C) Shows that few land cover changes have occurred while(D) shows the actual isoclustered Landsat data for the 1970s, 1990, and 2000, respectively. (E) Shows the trend in temperature and NDVI is synchronous in this maritime environment and (F) shows that the growing season had increased by $\sim 17$ days from 1992-1999. 
Table 1

Class Definitions for evaluation protocol

Class

Criteria

(NE) Needleleaf Evergreen Forests

Needleleaf Evergreen Trees $>3 \mathrm{~m}$ in height,

(MXF) Mixed Forests

Continuous Canopy $>30 \%$

(BD) Broadleaf Deciduous Forests

height, Continuous Canopy $>30 \%$

Broadleaf Deciduous Trees $>3 \mathrm{~m}$ in height, Continuous Canopy $>30 \%$

(DTS) Dwarf Trees/Scrublands

Trees and Shrubs $>1$ and $<3 \mathrm{~m}$ in height, Continuous Canopy $>30 \%$

(SVEG) Short Vegetation C3 Grasslands Herbaceous Vegetation < $1 \mathrm{~m}$ in height,

Sparse Canopy Density $<50 \%$

(AG) Agriculture C4 Grasslands

Annual Crops, Sparse Canopy Density $<50 \%$ Open Water Surfaces $>20 \%$

(W) Water

Human Built Structures, Roads, Bare Soil $>20 \%$

(B) Barren/Bare Soil/Urban

Clouds, Cloud Shadow, and Snow Cover $>20 \%$ 
Table 2

Error Matrices for Yukon

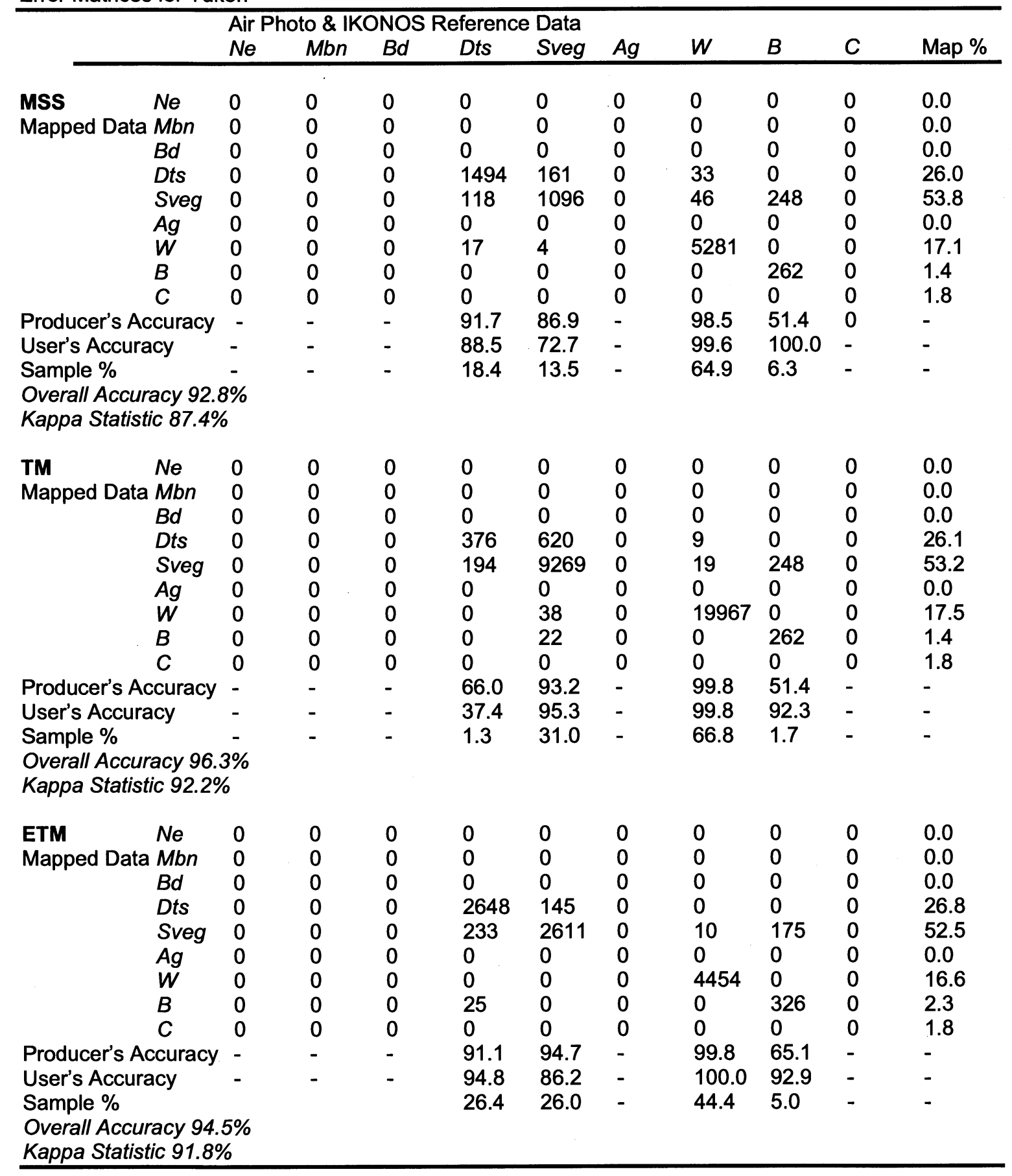


Table 3

Error Matrices for Northern Saskatchewan

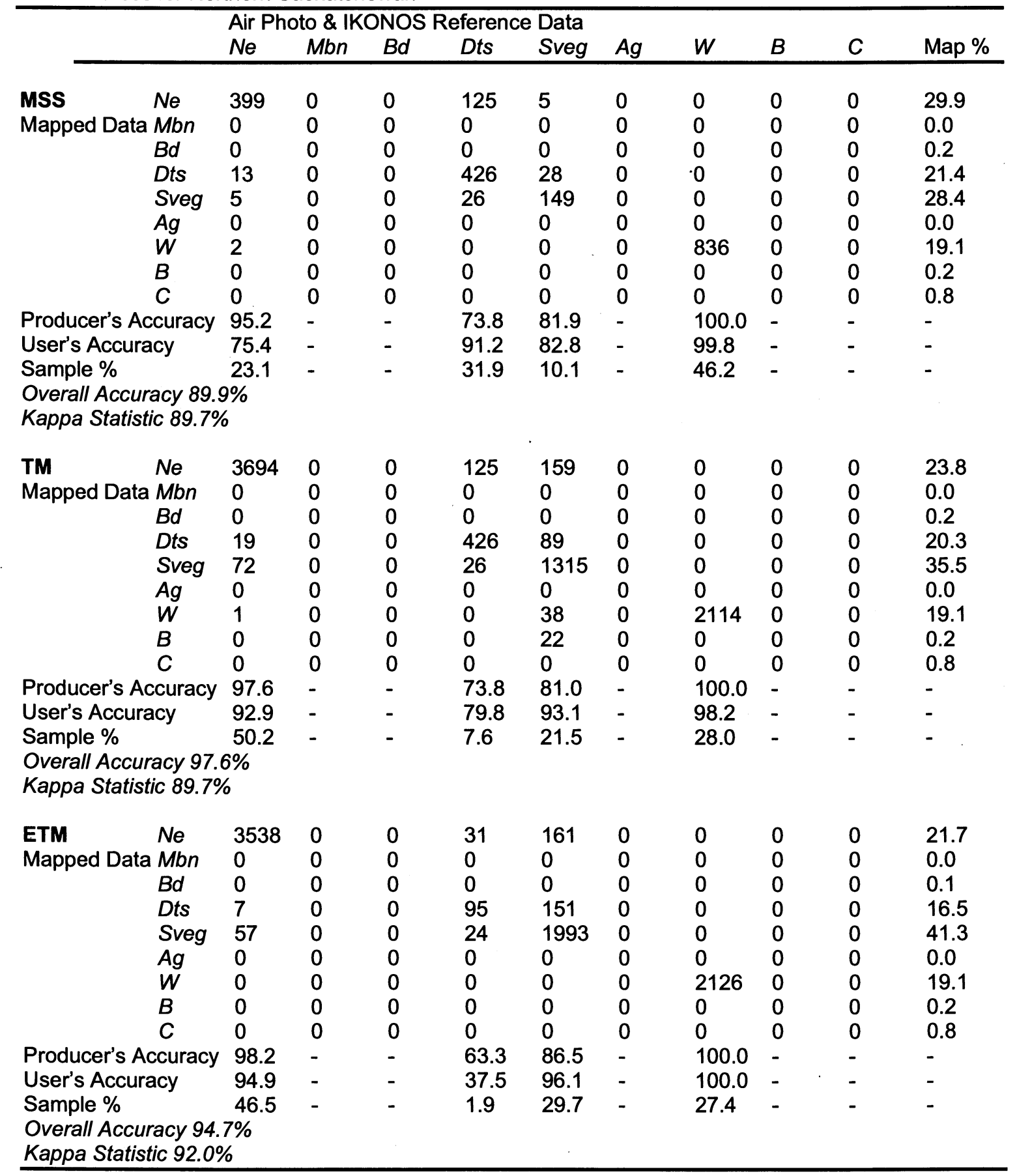


Table 4

Error Matrices for Southern Saskatchewan \& Dakotas

\begin{tabular}{|c|c|c|c|c|c|c|c|c|c|c|}
\hline & $\begin{array}{l}\text { Air } F \\
\mathrm{Ne}\end{array}$ & $\begin{array}{l}\text { to \& IK } \\
M b n\end{array}$ & $\begin{array}{l}\text { NOS } \\
B d\end{array}$ & $\begin{array}{l}\text { eferenc } \\
D t s\end{array}$ & $\begin{array}{l}\text { Data } \\
\text { Sveg }\end{array}$ & $A g$ & $w$ & $B$ & C & Мар \% \\
\hline $\begin{array}{ll}\text { MSS } & \text { Ne } \\
\text { Mapped Data } & \text { Mbn } \\
& B d \\
& D t s \\
& \text { Sveg } \\
& A g \\
& W \\
& B \\
& C \\
& \\
\text { Producer's Accuracy } \\
\text { User's Accuracy } \\
\text { Sample \% } \\
\text { Overall Accuracy } 88.9 \\
\text { Kappa Statistic } 82.8 \%\end{array}$ & $\begin{array}{l}0 \\
0 \\
0 \\
0 \\
0 \\
0 \\
0 \\
0 \\
0 \\
- \\
- \\
- \\
9 \% \\
6\end{array}$ & $\begin{array}{l}0 \\
0 \\
0 \\
0 \\
0 \\
0 \\
0 \\
0 \\
0 \\
- \\
- \\
-\end{array}$ & $\begin{array}{l}0 \\
0 \\
230 \\
0 \\
74 \\
83 \\
0 \\
4 \\
0 \\
58.8 \\
53.9 \\
1.7\end{array}$ & $\begin{array}{l}0 \\
0 \\
65 \\
98 \\
7 \\
19 \\
45 \\
0 \\
0 \\
41.9 \\
61.6 \\
1.0\end{array}$ & $\begin{array}{l}0 \\
0 \\
52 \\
0 \\
11631 \\
0 \\
0 \\
60 \\
0 \\
99.0 \\
91.3 \\
51.2\end{array}$ & $\begin{array}{l}0 \\
0 \\
80 \\
0 \\
952 \\
7634 \\
0 \\
133 \\
0 \\
86.8 \\
86.5 \\
38.4\end{array}$ & $\begin{array}{l}0 \\
0 \\
0 \\
4 \\
13 \\
1018 \\
2163 \\
67 \\
0 \\
66.2 \\
98.0 \\
14.2\end{array}$ & $\begin{array}{l}0 \\
0 \\
0 \\
57 \\
63 \\
69 \\
0 \\
1166 \\
0 \\
86.1 \\
81.5 \\
5.9\end{array}$ & $\begin{array}{l}0 \\
0 \\
0 \\
0 \\
0 \\
0 \\
0 \\
0 \\
0 \\
- \\
- \\
-\end{array}$ & $\begin{array}{l}0 \\
0 \\
1.8 \\
0.5 \\
58.8 \\
26.1 \\
2 \\
9 \\
0 \\
- \\
- \\
-\end{array}$ \\
\hline $\begin{array}{ll}\text { TM } & \text { Ne } \\
\text { Mapped Data } & \text { Mbn } \\
\text { Bd } \\
\text { Dts } \\
\text { Sveg } \\
A g \\
W \\
B \\
C \\
\\
\text { Producer's Accuracy } \\
\text { User's Accuracy } \\
\text { Sample \% } \\
\text { Overall Accuracy } 93.6 \\
\text { Kappa Statistic } 86.4 \%\end{array}$ & $\begin{array}{l}0 \\
0 \\
0 \\
0 \\
0 \\
0 \\
0 \\
0 \\
0 \\
- \\
- \\
- \\
6 \% \\
6\end{array}$ & $\begin{array}{l}0 \\
0 \\
0 \\
0 \\
0 \\
0 \\
0 \\
0 \\
0 \\
- \\
- \\
-\end{array}$ & $\begin{array}{l}0 \\
0 \\
169 \\
0 \\
15 \\
61 \\
0 \\
0 \\
0 \\
69.0 \\
75.1 \\
1.6\end{array}$ & $\begin{array}{l}0 \\
0 \\
0 \\
0 \\
0 \\
21 \\
0 \\
0 \\
0 \\
0.0 \\
0.0 \\
0.1\end{array}$ & $\begin{array}{l}0 \\
0 \\
21 \\
0 \\
10253 \\
364 \\
39 \\
28 \\
0 \\
95.8 \\
96.5 \\
70.4\end{array}$ & $\begin{array}{l}0 \\
0 \\
35 \\
0 \\
97 \\
1785 \\
0 \\
0 \\
0 \\
93.1 \\
78.9 \\
12.6\end{array}$ & $\begin{array}{l}0 \\
0 \\
0 \\
0 \\
1 \\
3 \\
10 \\
0 \\
0 \\
71.4 \\
20.4 \\
0.1\end{array}$ & $\begin{array}{l}0 \\
0 \\
0 \\
0 \\
256 \\
29 \\
0 \\
2019 \\
0 \\
87.6 \\
98.6 \\
15.2\end{array}$ & $\begin{array}{l}0 \\
0 \\
0 \\
0 \\
0 \\
0 \\
0 \\
0 \\
0 \\
- \\
- \\
-\end{array}$ & $\begin{array}{l}0 \\
0 \\
0.9 \\
1.9 \\
65.1 \\
13.5 \\
0.3 \\
18.1 \\
0.1 \\
- \\
- \\
-\end{array}$ \\
\hline $\begin{array}{ll}\text { ETM } & \text { Ne } \\
\text { Mapped Data } M b n \\
\\
\text { Bd } \\
\text { Dts } \\
\text { Sveg } \\
\text { Ag } \\
\text { W } \\
\text { B } \\
C \\
\text { Producer's Accuracy } \\
\text { User's Accuracy } \\
\text { Sample \% } \\
\text { Overall Accuracy } 91.2 \\
\text { Kappa Statistic } 86.7 \%\end{array}$ & $\begin{array}{l}0 \\
0 \\
0 \\
0 \\
0 \\
0 \\
0 \\
0 \\
0 \\
- \\
- \\
- \\
2 \% \\
0\end{array}$ & $\begin{array}{l}0 \\
0 \\
0 \\
0 \\
0 \\
0 \\
0 \\
0 \\
0 \\
- \\
- \\
-\end{array}$ & $\begin{array}{l}0 \\
0 \\
149 \\
0 \\
31 \\
25 \\
0 \\
2 \\
0 \\
72.0 \\
65.9 \\
2.9\end{array}$ & $\begin{array}{l}0 \\
0 \\
16 \\
0 \\
14 \\
0 \\
0 \\
0 \\
0 \\
0.0 \\
0.0 \\
0.4\end{array}$ & $\begin{array}{l}0 \\
0 \\
11 \\
0 \\
3466 \\
86 \\
0 \\
100 \\
0 \\
94.6 \\
90.2 \\
50.7\end{array}$ & $\begin{array}{l}0 \\
0 \\
50 \\
0 \\
288 \\
2311 \\
0 \\
5 \\
0 \\
89.1 \\
94.4 \\
35.9\end{array}$ & $\begin{array}{l}0 \\
0 \\
0 \\
0 \\
0 \\
0 \\
651 \\
0 \\
0 \\
100.0 \\
100.0 \\
9.0\end{array}$ & $\begin{array}{l}0 \\
0 \\
0 \\
0 \\
103 \\
25 \\
0 \\
653 \\
0 \\
83.6 \\
85.9 \\
10.8\end{array}$ & $\begin{array}{l}0 \\
0 \\
0 \\
0 \\
0 \\
0 \\
0 \\
0 \\
0 \\
- \\
- \\
-\end{array}$ & $\begin{array}{l}0 \\
0 \\
2.2 \\
0.4 \\
52.5 \\
26.7 \\
2.9 \\
13.5 \\
1.8 \\
- \\
- \\
-\end{array}$ \\
\hline
\end{tabular}


Table 5

Error Matrices for Oklahoma Panhandle

\begin{tabular}{|c|c|c|c|c|c|c|c|c|c|c|}
\hline & $\begin{array}{l}\text { Air F } \\
\mathrm{Ne}\end{array}$ & $\begin{array}{l}\text { to \& IK } \\
M b n\end{array}$ & $\begin{array}{l}\text { NOS R } \\
B d\end{array}$ & $\begin{array}{l}\text { eferenc } \\
\text { Dts }\end{array}$ & $\begin{array}{l}\text { Data } \\
\text { Sveg }\end{array}$ & $A g$ & $w$ & $B$ & $C$ & Map \% \\
\hline 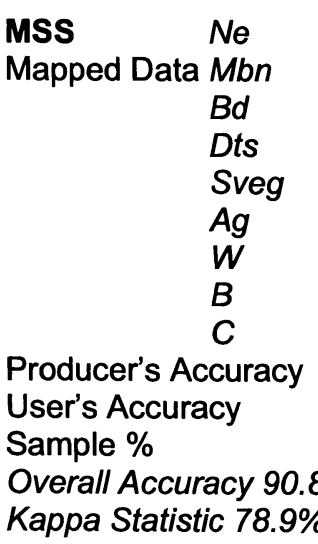 & $\begin{array}{l}0 \\
0 \\
0 \\
0 \\
0 \\
0 \\
0 \\
0 \\
0 \\
- \\
- \\
- \\
8 \% \\
0\end{array}$ & $\begin{array}{l}0 \\
0 \\
0 \\
0 \\
0 \\
0 \\
0 \\
0 \\
0 \\
- \\
- \\
-\end{array}$ & $\begin{array}{l}0 \\
0 \\
131 \\
112 \\
31 \\
0 \\
0 \\
2 \\
0 \\
47.5 \\
100.0 \\
0.7\end{array}$ & $\begin{array}{l}0 \\
0 \\
0 \\
55 \\
17 \\
7 \\
0 \\
0 \\
0 \\
69.6 \\
39.2 \\
0.2\end{array}$ & $\begin{array}{l}0 \\
0 \\
0 \\
0 \\
28109 \\
119 \\
0 \\
1843 \\
0 \\
93.5 \\
94.8 \\
79.8\end{array}$ & $\begin{array}{l}0 \\
0 \\
0 \\
0 \\
400 \\
2434 \\
0 \\
57 \\
0 \\
84.2 \\
93.2 \\
7.7\end{array}$ & $\begin{array}{l}0 \\
0 \\
0 \\
0 \\
0 \\
0 \\
16 \\
5 \\
0 \\
76.2 \\
21.9 \\
0.1\end{array}$ & $\begin{array}{l}0 \\
0 \\
0 \\
0 \\
1100 \\
52 \\
57 \\
6926 \\
0 \\
85.1 \\
78.4 \\
21.6\end{array}$ & $\begin{array}{l}0 \\
0 \\
0 \\
0 \\
0 \\
0 \\
0 \\
0 \\
0 \\
- \\
- \\
-\end{array}$ & $\begin{array}{l}0 \\
0 \\
0.9 \\
1.9 \\
66.8 \\
12.4 \\
0.3 \\
17.6 \\
0.1 \\
- \\
- \\
-\end{array}$ \\
\hline $\begin{array}{ll}\text { TM } & \text { Ne } \\
\text { Mapped Data } M b n \\
B d \\
\text { Dts } \\
\text { Sveg } \\
A g \\
W \\
B \\
C \\
\text { Producer's Accuracy } \\
\text { User's Accuracy } \\
\text { Sample \% } \\
\text { Overall Accuracy 91. } \\
\text { Kappa Statistic } 83.1 \%\end{array}$ & $\begin{array}{l}0 \\
0 \\
0 \\
0 \\
0 \\
0 \\
0 \\
0 \\
0 \\
- \\
- \\
- \\
7 \% \\
\%\end{array}$ & $\begin{array}{l}0 \\
0 \\
0 \\
0 \\
0 \\
0 \\
0 \\
0 \\
0 \\
- \\
- \\
-\end{array}$ & $\begin{array}{l}0 \\
0 \\
164 \\
0 \\
24 \\
22 \\
6 \\
0 \\
0 \\
75.9 \\
99.4 \\
1.7\end{array}$ & $\begin{array}{l}0 \\
0 \\
0 \\
0 \\
0 \\
0 \\
0 \\
0 \\
0 \\
- \\
- \\
-\end{array}$ & $\begin{array}{l}0 \\
0 \\
1 \\
0 \\
8720 \\
417 \\
0 \\
447 \\
0 \\
91.0 \\
97.9 \\
76.0\end{array}$ & $\begin{array}{l}0 \\
0 \\
0 \\
0 \\
45 \\
773 \\
0 \\
1 \\
0 \\
94.4 \\
61.3 \\
6.5\end{array}$ & $\begin{array}{l}0 \\
0 \\
0 \\
0 \\
0 \\
0 \\
99 \\
0 \\
0 \\
100.0 \\
94.3 \\
0.8\end{array}$ & $\begin{array}{l}0 \\
0 \\
0 \\
0 \\
122 \\
49 \\
0 \\
2849 \\
0 \\
94.3 \\
86.4 \\
24.0\end{array}$ & $\begin{array}{l}0 \\
0 \\
0 \\
0 \\
0 \\
0 \\
0 \\
0 \\
0 \\
0 \\
0 \\
0\end{array}$ & $\begin{array}{l}0.0 \\
0.0 \\
0.9 \\
1.9 \\
65.1 \\
13.5 \\
0.3 \\
18.1 \\
0.1 \\
- \\
- \\
-\end{array}$ \\
\hline $\begin{array}{ll}\text { ETM } & N e \\
\text { Mapped Data } & M b n \\
& B d \\
& \text { Dts } \\
\text { Sveg } & \\
& A g \\
W & \\
& \text { C } \\
& \\
\text { Producer's Accuracy } \\
\text { User's Accuracy } \\
\text { Sample \% } \\
\text { Overall Accuracy } 87 . \\
\text { Kappa Statistic } 77.3 \%\end{array}$ & $\begin{array}{l}0 \\
0 \\
0 \\
0 \\
0 \\
0 \\
0 \\
0 \\
0 \\
- \\
- \\
- \\
6 \% \\
\%\end{array}$ & $\begin{array}{l}0 \\
0 \\
0 \\
0 \\
0 \\
0 \\
0 \\
0 \\
0 \\
- \\
- \\
-\end{array}$ & $\begin{array}{l}0 \\
0 \\
55 \\
0 \\
47 \\
0 \\
0 \\
0 \\
0 \\
53.9 \\
100.0 \\
0.6\end{array}$ & $\begin{array}{l}0 \\
0 \\
0 \\
0 \\
0 \\
0 \\
0 \\
0 \\
0 \\
- \\
- \\
-\end{array}$ & $\begin{array}{l}0 \\
0 \\
0 \\
0 \\
2340 \\
0 \\
0 \\
50 \\
0 \\
97.7 \\
51.9 \\
14.9\end{array}$ & $\begin{array}{l}0 \\
0 \\
0 \\
0 \\
12 \\
3255 \\
0 \\
37 \\
0 \\
98.5 \\
99.7 \\
20.6\end{array}$ & $\begin{array}{l}0 \\
0 \\
0 \\
0 \\
0 \\
0 \\
22 \\
0 \\
0 \\
100.0 \\
100.0 \\
0.1\end{array}$ & $\begin{array}{l}0 \\
0 \\
0 \\
0 \\
2110 \\
10 \\
0 \\
10351 \\
0 \\
83.0 \\
99.2 \\
77.8\end{array}$ & $\begin{array}{l}0 \\
0 \\
0 \\
0 \\
0 \\
0 \\
0 \\
0 \\
0 \\
- \\
- \\
-\end{array}$ & $\begin{array}{l}0 \\
0 \\
1.0 \\
2.0 \\
62.0 \\
15.2 \\
0.4 \\
19.2 \\
0.1 \\
- \\
- \\
-\end{array}$ \\
\hline
\end{tabular}


Table 6

Error Matrices for Quebec

\begin{tabular}{|c|c|c|c|c|c|c|c|c|c|c|}
\hline & $\begin{array}{l}\text { Air Ph } \\
\mathrm{Ne}\end{array}$ & $\begin{array}{l}\text { to \& IKC } \\
M b n\end{array}$ & $\begin{array}{l}\text { NOS } \\
B d\end{array}$ & $\begin{array}{l}\text { eferenc } \\
D t s\end{array}$ & $\begin{array}{l}\text { Data } \\
\text { Sveg }\end{array}$ & $A g$ & $w$ & $B$ & C & Мap \% \\
\hline $\begin{array}{lc}\text { MSS } & \text { Ne } \\
\text { Mapped Data } & \text { Mbn } \\
& B d \\
& D t s \\
& \text { Sveg } \\
& A g \\
W & \\
& B \\
& C \\
& \\
\text { Producer's Accuracy } \\
\text { User's Accuracy } \\
\text { Sample \% } \\
\text { Overall Accuracy } 92.6 \\
\text { Kappa Statistic } 86.8 \%\end{array}$ & $\begin{array}{l}4534 \\
0 \\
17 \\
19 \\
164 \\
12 \\
0 \\
0 \\
0 \\
95.5 \\
97.4 \\
67.0 \\
6 \% \\
6\end{array}$ & $\begin{array}{l}9 \\
48 \\
36 \\
0 \\
14 \\
0 \\
0 \\
0 \\
0 \\
44.9 \\
100.0 \\
0.7\end{array}$ & $\begin{array}{l}1 \\
0 \\
671 \\
5 \\
135 \\
0 \\
0 \\
0 \\
0 \\
82.6 \\
92.7 \\
9.9\end{array}$ & $\begin{array}{l}11 \\
0 \\
0 \\
101 \\
1 \\
0 \\
0 \\
0 \\
0 \\
89.4 \\
78.3 \\
1.5\end{array}$ & $\begin{array}{l}89 \\
0 \\
0 \\
0 \\
566 \\
0 \\
0 \\
0 \\
0 \\
86.4 \\
64.3 \\
8.4\end{array}$ & $\begin{array}{l}0 \\
0 \\
0 \\
0 \\
0 \\
0 \\
0 \\
0 \\
0 \\
- \\
- \\
-\end{array}$ & $\begin{array}{l}12 \\
0 \\
0 \\
4 \\
0 \\
0 \\
844 \\
0 \\
0 \\
98.1 \\
100.0 \\
12.5\end{array}$ & $\begin{array}{l}0 \\
0 \\
0 \\
0 \\
0 \\
0 \\
0 \\
0 \\
0 \\
- \\
- \\
-\end{array}$ & $\begin{array}{l}0 \\
0 \\
0 \\
0 \\
0 \\
0 \\
0 \\
0 \\
0 \\
- \\
- \\
-\end{array}$ & $\begin{array}{l}47.9 \\
2.4 \\
18.2 \\
4.1 \\
12.9 \\
1.8 \\
12.1 \\
0.2 \\
0.5 \\
- \\
- \\
-\end{array}$ \\
\hline $\begin{array}{ll}\text { TM } & \text { Ne } \\
\text { Mapped Data } & M b n \\
B d & \\
D t s \\
\text { Sveg } \\
A g \\
W \\
B \\
C \\
\text { Producer's Accuracy } \\
\text { User's Accuracy } \\
\text { Sample \% } \\
\text { Overall Accuracy } 92.3 \\
\text { Kappa Statistic } 89.3 \%\end{array}$ & $\begin{array}{l}1520 \\
8 \\
70 \\
4 \\
3 \\
0 \\
0 \\
0 \\
0 \\
94.7 \\
88.3 \\
37.2 \\
3 \% \\
6\end{array}$ & $\begin{array}{l}0 \\
24 \\
3 \\
0 \\
3 \\
0 \\
0 \\
0 \\
0 \\
80.0 \\
39.3 \\
0.6\end{array}$ & $\begin{array}{l}84 \\
18 \\
263 \\
0 \\
0 \\
0 \\
0 \\
1 \\
0 \\
71.9 \\
76.9 \\
6.4\end{array}$ & $\begin{array}{l}70 \\
0 \\
0 \\
138 \\
10 \\
0 \\
0 \\
0 \\
0 \\
63.3 \\
94.5 \\
3.4\end{array}$ & $\begin{array}{l}34 \\
11 \\
6 \\
0 \\
742 \\
0 \\
0 \\
0 \\
0 \\
93.6 \\
97.9 \\
18.1\end{array}$ & $\begin{array}{l}0 \\
0 \\
0 \\
0 \\
0 \\
0 \\
0 \\
0 \\
0 \\
- \\
- \\
-\end{array}$ & $\begin{array}{l}12 \\
0 \\
0 \\
4 \\
0 \\
0 \\
1405 \\
0 \\
0 \\
98.8 \\
100.0 \\
34.3\end{array}$ & $\begin{array}{l}0 \\
0 \\
0 \\
0 \\
0 \\
0 \\
0 \\
0 \\
0 \\
- \\
- \\
-\end{array}$ & $\begin{array}{l}0 \\
0 \\
0 \\
0 \\
0 \\
0 \\
0 \\
0 \\
0 \\
- \\
- \\
-\end{array}$ & $\begin{array}{l}41.6 \\
2.7 \\
20.2 \\
4.6 \\
16.2 \\
1.9 \\
12.2 \\
0.2 \\
0.5 \\
- \\
- \\
-\end{array}$ \\
\hline $\begin{array}{ll}\text { ETM } & \text { Ne } \\
\text { Mapped Data } & M b n \\
& B d \\
& D t s \\
& \text { Sveg } \\
& A g \\
W & \\
& B \\
C \\
\text { Producer's Accuracy } \\
\text { User's Accuracy } \\
\text { Sample \% } \\
\text { Overall Accuracy } 89.8 \\
\text { Kappa Statistic } 86.8 \%\end{array}$ & $\begin{array}{l}1532 \\
0 \\
114 \\
10 \\
7 \\
0 \\
0 \\
0 \\
0 \\
92.1 \\
98.5 \\
38.4 \\
8 \% \\
\end{array}$ & $\begin{array}{l}0 \\
163 \\
33 \\
0 \\
6 \\
0 \\
0 \\
0 \\
0 \\
80.7 \\
61.5 \\
4.1\end{array}$ & $\begin{array}{l}23 \\
84 \\
558 \\
7 \\
71 \\
0 \\
0 \\
0 \\
0 \\
75.1 \\
78.4 \\
14.0\end{array}$ & $\begin{array}{l}0 \\
0 \\
0 \\
277 \\
27 \\
0 \\
0 \\
1 \\
0 \\
90.8 \\
82.2 \\
6.9\end{array}$ & $\begin{array}{l}1 \\
18 \\
7 \\
43 \\
790 \\
0 \\
0 \\
0 \\
0 \\
92.0 \\
87.8 \\
19.8\end{array}$ & $\begin{array}{l}0 \\
0 \\
0 \\
0 \\
0 \\
0 \\
0 \\
0 \\
0 \\
- \\
- \\
-\end{array}$ & $\begin{array}{l}0 \\
0 \\
0 \\
0 \\
0 \\
0 \\
669 \\
0 \\
0 \\
100.0 \\
100.0 \\
16.8\end{array}$ & $\begin{array}{l}0 \\
0 \\
0 \\
0 \\
0 \\
0 \\
0 \\
0 \\
0 \\
- \\
- \\
-\end{array}$ & $\begin{array}{l}0 \\
0 \\
0 \\
0 \\
0 \\
0 \\
0 \\
0 \\
0 \\
- \\
- \\
-\end{array}$ & $\begin{array}{l}34.2 \\
3.0 \\
21.4 \\
5.6 \\
20.5 \\
2.2 \\
12.3 \\
0.3 \\
0.5 \\
- \\
- \\
-\end{array}$ \\
\hline
\end{tabular}


Table 7

Error Matrices for Newfoundland

\begin{tabular}{|c|c|c|c|c|c|c|c|c|c|c|}
\hline & $\begin{array}{l}\text { Air Ph } \\
\mathrm{Ne} \\
\end{array}$ & $\begin{array}{l}\text { to \& IK } \\
M b n\end{array}$ & $\begin{array}{l}\text { NOS F } \\
B d\end{array}$ & $\begin{array}{l}\text { eferenc } \\
D t s \\
\end{array}$ & $\begin{array}{l}\text { Data } \\
\text { Sveg }\end{array}$ & $A g$ & $w$ & $B$ & $C$ & Map \% \\
\hline $\begin{array}{ll}\text { MSS } & \text { Ne } \\
\text { Mapped Data } & \text { Mbn } \\
& B d \\
& D t s \\
& \text { Sveg } \\
& A g \\
& W \\
& B \\
& C \\
& \\
& \\
\text { Producer's Accuracy } \\
\text { User's Accuracy } \\
\text { Sample \% } \\
\text { Overall Accuracy } 80.7 \\
\text { Kappa Statistic 68.4\% }\end{array}$ & $\begin{array}{l}79 \\
5 \\
0 \\
1 \\
19 \\
0 \\
0 \\
0 \\
0 \\
76.0 \\
7.6 \\
0.7 \\
7 \% \\
0\end{array}$ & $\begin{array}{l}10 \\
12 \\
0 \\
0 \\
53 \\
0 \\
0 \\
4 \\
4 \\
14.5 \\
4.8 \\
0.1\end{array}$ & $\begin{array}{l}17 \\
72 \\
74 \\
16 \\
406 \\
0 \\
0 \\
0 \\
3 \\
12.6 \\
32.6 \\
0.6\end{array}$ & $\begin{array}{l}0 \\
45 \\
144 \\
54 \\
379 \\
0 \\
2 \\
9 \\
5 \\
8.4 \\
18.4 \\
0.5\end{array}$ & $\begin{array}{l}932 \\
111 \\
8 \\
222 \\
5617 \\
0 \\
17 \\
53 \\
183 \\
78.6 \\
86.7 \\
48.5\end{array}$ & $\begin{array}{l}0 \\
0 \\
0 \\
0 \\
0 \\
0 \\
0 \\
0 \\
0 \\
- \\
- \\
-\end{array}$ & $\begin{array}{l}0 \\
0 \\
0 \\
0 \\
0 \\
0 \\
5751 \\
0 \\
45 \\
99.2 \\
99.7 \\
49.6\end{array}$ & $\begin{array}{l}0 \\
0 \\
1 \\
0 \\
2 \\
0 \\
0 \\
0 \\
6 \\
0.0 \\
0.0 \\
0.0\end{array}$ & $\begin{array}{l}0 \\
0 \\
0 \\
0 \\
0 \\
0 \\
0 \\
0 \\
0 \\
- \\
- \\
-\end{array}$ & $\begin{array}{l}39.1 \\
3.3 \\
1.5 \\
6.8 \\
31.2 \\
0 \\
7.9 \\
3 \\
7.2 \\
- \\
- \\
-\end{array}$ \\
\hline 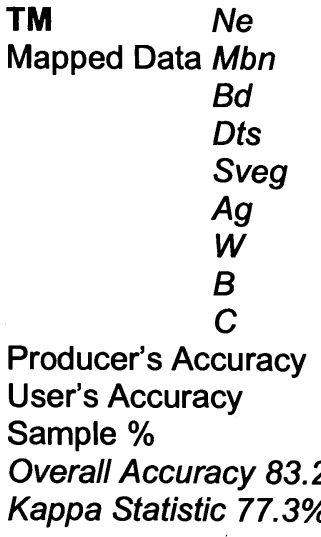 & $\begin{array}{l}7289 \\
444 \\
8 \\
160 \\
1648 \\
0 \\
29 \\
15 \\
57 \\
75.5 \\
89.5 \\
24.8 \\
2 \% \\
\%\end{array}$ & $\begin{array}{l}361 \\
1220 \\
151 \\
194 \\
256 \\
0 \\
0 \\
46 \\
4 \\
54.7 \\
62.0 \\
4.1\end{array}$ & $\begin{array}{l}76 \\
54 \\
351 \\
86 \\
361 \\
0 \\
4 \\
36 \\
3 \\
36.1 \\
55.8 \\
1.2\end{array}$ & $\begin{array}{l}13 \\
21 \\
65 \\
90 \\
252 \\
0 \\
4 \\
13 \\
5 \\
19.4 \\
15.7 \\
0.3\end{array}$ & $\begin{array}{l}385 \\
210 \\
49 \\
35 \\
6856 \\
0 \\
12 \\
472 \\
183 \\
83.6 \\
71.1 \\
22.7\end{array}$ & $\begin{array}{l}0 \\
0 \\
0 \\
0 \\
0 \\
0 \\
0 \\
0 \\
0 \\
- \\
- \\
-\end{array}$ & $\begin{array}{l}11 \\
15 \\
3 \\
5 \\
79 \\
0 \\
13116 \\
2 \\
45 \\
98.8 \\
99.6 \\
43.5\end{array}$ & $\begin{array}{l}12 \\
3 \\
2 \\
4 \\
187 \\
0 \\
4 \\
1235 \\
6 \\
85.0 \\
67.9 \\
4.1\end{array}$ & $\begin{array}{l}0 \\
0 \\
0 \\
0 \\
0 \\
0 \\
0 \\
0 \\
0 \\
- \\
- \\
-\end{array}$ & $\begin{array}{l}36.1 \\
3.4 \\
1.6 \\
7.1 \\
33 \\
0 \\
8 \\
3.5 \\
7.2 \\
- \\
- \\
-\end{array}$ \\
\hline $\begin{array}{ll}\text { ETM } & \text { Ne } \\
\text { Mapped Data } & M b n \\
& B d \\
& D t s \\
& \text { Sveg } \\
A g & \\
W & \\
& B \\
& \\
& \\
\text { Producer's Accuracy } \\
\text { User's Accuracy } \\
\text { Sample \% } \\
\text { Overall Accuracy } 92 . \\
\text { Kappa Statistic } 88.8 \%\end{array}$ & $\begin{array}{l}1867 \\
7 \\
0 \\
14 \\
1 \\
0 \\
0 \\
0 \\
0 \\
98.8 \\
89.6 \\
42.5 \\
5 \% \\
\%\end{array}$ & $\begin{array}{l}153 \\
137 \\
0 \\
0 \\
0 \\
0 \\
0 \\
0 \\
0 \\
47.2 \\
88.4 \\
3.12\end{array}$ & $\begin{array}{l}0 \\
0 \\
0 \\
0 \\
0 \\
0 \\
0 \\
0 \\
0 \\
- \\
- \\
-\end{array}$ & $\begin{array}{l}8 \\
11 \\
0 \\
213 \\
47 \\
0 \\
0 \\
0 \\
0 \\
76.3 \\
82.2 \\
4.9\end{array}$ & $\begin{array}{l}50 \\
0 \\
0 \\
32 \\
1700 \\
0 \\
0 \\
16 \\
0 \\
94.5 \\
96.6 \\
38.7\end{array}$ & $\begin{array}{l}0 \\
0 \\
0 \\
0 \\
0 \\
0 \\
0 \\
0 \\
0 \\
- \\
- \\
-\end{array}$ & $\begin{array}{l}5 \\
0 \\
0 \\
0 \\
0 \\
0 \\
451 \\
0 \\
0 \\
98.9 \\
100.0 \\
10.3\end{array}$ & $\begin{array}{l}1 \\
0 \\
0 \\
0 \\
11 \\
0 \\
0 \\
30 \\
0 \\
71.4 \\
65.2 \\
0.7\end{array}$ & $\begin{array}{l}0 \\
0 \\
0 \\
0 \\
0 \\
0 \\
0 \\
0 \\
0 \\
- \\
- \\
-\end{array}$ & $\begin{array}{l}35.1 \\
3.4 \\
1.7 \\
7.2 \\
33.4 \\
0.0 \\
8.0 \\
3.8 \\
7.2 \\
- \\
- \\
-\end{array}$ \\
\hline
\end{tabular}


Table 8

Landsat scenes used in investigation, bold indicates duplicates for overlap.

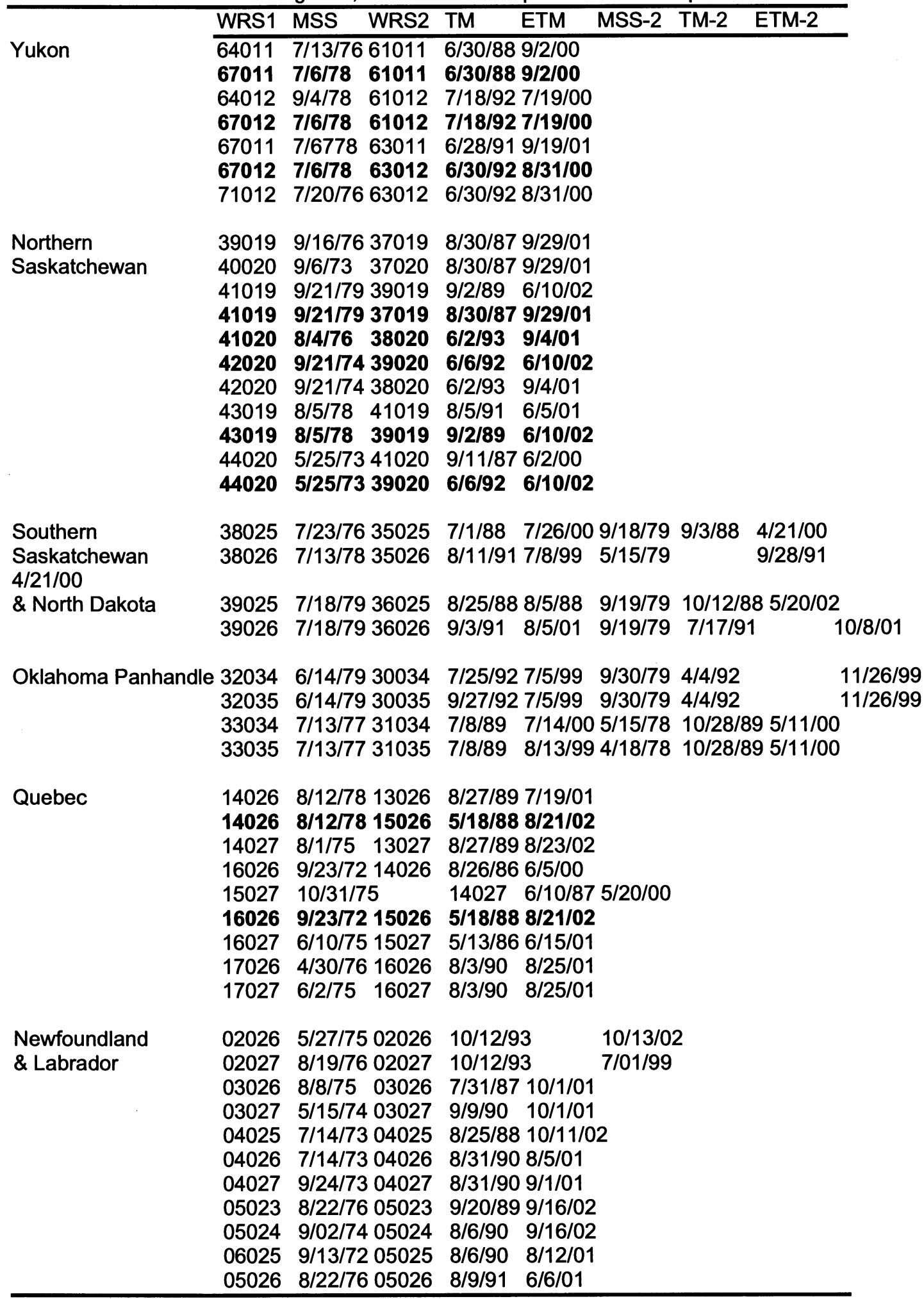


Table 8 (continued)

Landsat scenes used in investigation, bold indicates duplicates for overlap.

\begin{tabular}{llllll}
\hline & WRS1 & MSS & WRS2 & TM & ETM \\
\cline { 2 - 6 } Newfoundland & $\mathbf{0 6 0 2 6}$ & $9 / 26 / 73$ & 05026 & $\mathbf{8} / 9 / 91$ & $6 / 6 / 00$ \\
\& Labrador & 05027 & $6 / 4 / 74$ & 05027 & $8 / 9 / 91$ & $6 / 6 / 00$ \\
& 06023 & $6 / 30 / 76$ & 06023 & $8 / 18 / 92$ & $9 / 20 / 01$ \\
& $\mathbf{0 8 0 2 3}$ & $10 / 3 / 72$ & 06023 & $\mathbf{8} / 18 / 92$ & $9 / 20 / 01$ \\
& 08022 & $7 / 8 / 75$ & $\mathbf{0 6 0 2 3}$ & $\mathbf{8} / 18 / 92$ & $9 / 20 / 01$ \\
& 06024 & $10 / 19 / 72$ & 06024 & $6 / 15 / 92$ & $9 / 20 / 01$ \\
& 07024 & $7 / 19 / 73$ & 06024 & $6 / 15 / 92$ & $9 / 20 / 01$ \\
\hline
\end{tabular}




\section{References:}

Afanasyev, Y. D., Nezlin, N. P. \& Kostianoy, A. G. (2001). Patterns of seasonal dynamics of remotely sensed chlorophyll and physical environment in the Newfoundland region. Remote Sensing of Environment, 76, 268-282.

Alma Quebec Canada, (2006). A Growing Population, Available Online at: http://www.ville.alma.qc.ca/anglais/investisseur/profil-population.html (accessed 11-29-06).

Amiro, B. D., Todd, J. B., Wotton, B. M., Logan, K. A., Flannigan, M. D., Stocks, B. J., Mason, J. A., Martell, D. L. \& Hirsch, K. G. (2001). Direct carbon emissions from Canadian forest fires, 1959-1999. Canadian Journal of Forest Research Revue Canadienne De Recherche Forestiere, 31, 512-525.

Angert, A., Biraud, S. \& Bonfils, C. (2005). Drier summers cancel out the CO2 uptake enhancement induced by warmer springs. Proceedings of the National Academy of Sciences of the United States of America, 102, 10823-10827.

Archibold, O. W., (1995). Ecology of World Vegetation. 510.

Auclair, A. N. D., Bouchard, A. \& Pajaczkowski, J. (1976). Concentration, mass and distribution of nutrients in a subarctic Picea mariana-Cladonia alpestris ecosystem. Canadian Journal of Forest Research - Revue Canadienne De Recherche Forestiere, 12, 947-968.

Ayres, M. P. \& Lombardero, M. J. (2000). Assessing the consequences of global change for forest disturbance from herbivores and pathogens. The science of the total environment, 262, 263-286.

Baldocchi, D. D. \& Amthor, J. S., (2001). Canopy Photosynthesis: History Measurements, and Models. Terrestrial Global Productivity, 573.

Barber, V., Juday, G. \& Finney, B. (2000). Reduced growth of Alaskan white spruce in the twentieth century from temperature-induced drought stress. Nature, 405, 668673.

Baskerville, G. L. (1975). Spruce budworm: The answer is forest management: or is it? Forest Chronologies, 51, 157-160.

Benedetti, R. \& Rossini, P. (1993). On the use of NDVI profiles as a tool for agriculture statistics: The case study of wheat yield estimate and forecast in Emilia Romagna. Remote Sensing of Environment, 45, 311-326.

Blias, J. R. (1981). Mortality of balsam fir and white spruce following a spruce budworm outbreak in the Ottawa River watershed in Quebec. Canadian Journal of Forest Research, 11, 620-629.

Blias, J. R. (1983). Trends in the frequency, extent and severity of spruce budworm outbreaks in eastern Canada. Canadian Journal of Forest Research, 13, 539-547.

Blias, J. R. (1985). The ecology of the eastern spruce budworm: A review and discussion. Canadian Forestry Service, 49-59.

Boissard, P., Pointel, J. G. \& Huet, P. (1993). Reflectance, green leaf area index and ear hydric status of wheat from anthesis until maturity. International Journal of Remote Sensing, 14, 2713-2729.

Brovokin, V., Sitch, S., Bloh, W. v., Claussen, M., Bauer, E. \& Cramer, W. (2004). Role of land cover changes for atmospheric $\mathrm{CO}_{2}$ increase and climate change during the last 150 years. Global Change Biology, 10, 1253-1266.

Brown, M. E., Pinzon, J. E. \& Tucker, C. J. (2004). New Vegetation Index Data Set Available to Monitor Global Change. EOS Transactions, 85, 565-569. 
Natural Resources Canada, (2006). Forestry Statistics, Available Online at: http://www.nrcan.gc.ca/cfs (accessed 11-29-06).

Caspersen, J. P., Pacala, S. W., Jenkins, J. C., Hurtt, G. C., Moorcroft, P. R. \& Birdsey, R. A. (2000). Contributions of Land-Use History to Carbon Accumulation in U.S. Forests. Science, 290, 1148-1151.

Chapin, F. S., McGuire, A. D., Randerson, J., Pielke, R., Baldocchi, D., Hobbie, S. E., Roulet, N., Eugster, W., Kasischke, E., Rastetter, E. B., Zimov, S. A. \& Running, S. W. (2000). Arctic and boreal ecosystems of western North America as components of the climate system. Global Change Biology, 6, 211-223.

Chen, W., Zhang, Y., Cihlar, J., Smith, S. L. \& Riseborough, D. W. (2003). Changes in soil temperature and active layer thickness during the twentieth century in a region in western Canada. Journal of Geophysical Research, 108, ACL 6-1, 6-13.

Ciais, P., Reichstein, M., Viovy, N., Granier, A., Ogee, J., Allard, V., Aubinet, M., Buchmann, N., Bernhofer, C., Carrara, A., Chevallier, F., Noblet, N. D., Friend, A. D., Freidlingstein, P., Grunwald, T., Heinesch, B., Keronen, P., Knohl, A., Krinner, G., Loustau, D., Manca, G., Matteucci, G., Miglietta, F., Ourcival, J. M., Papale, D., Pilegaard, K., Rambal, S., Seufert, G., Soussana, J. F., Sanz, M. J., Schulze, E. D., Vesala, T. \& Valentini, R. (2005). Europe-wide reduction in primary productivity caused by the heat and drought in 2003 . Nature, 437,529 533.

Cole, D. W. \& Rapp, M., (1981). Elemental cycling in forest ecosystems. Dynamic Properties for Forest Ecosystems, 341-409.

Covich, A. P., Fritz, S. C., Lamb, P. J., Marzolf, R. D., Matthews, W. J., Poiani, K. A., Prepas, E. E., Richman, M. B. \& Winter, T. C. (1997). Potential Effects of Climate Change on Aquatic Ecosystems of the Great Plains of North America. Hydrological Processes, 11, 993-1021.

Crist, E. P. \& Cicone, R. C. (1984). Application of the Tasseled Cap concept to simulated Thematic Mapper data. Photogrammetric Engineering and Remote Sensing, 50, 343-352.

Dai, A., Trenberth, K. E. \& Qian, T. (2004). A Global Dataset of Palmer Drought Severity Index for 1870-2002: Relationship with Soil Moisture and Effects of Surface Warming. Journal of Hydrometerology, 5, 1117-1130.

DeFries, R., Field, C. B., Fung, I., Collatz, G. J. \& Bounoua, L. (1999). Combining satellite data and biogeochemical models to estimate global effects of humaninduced land cover change on carbon emissions and primary productivity. Global Biogeochemical Cycles, 13, 803-815.

Domenikiotis, C., Dalezios, N. R., Loukas, A. \& Karteris, M. (2002). Agreement assessment of NOAA/AVHRR NDVI with Landsat TM NDVI for mapping burned forested areas. International Journal of Remote Sensing, 23, 4235-4246.

Doraiswamy, P. C. \& Cook, P. W. (1995). Spring wheat yield assessment using NOAA AVHRR data. Canadian Journal of Remote Sensing, 21, 43-51.

Dye, D. G. \& Tucker, C. J. (2003). Seasonality and trends of snow-cover, vegetation index, and temperature in northern Eurasia. Geophysical Research Letters, 30, 5851, 58-54.

Epstein, H. E., Calef, M. P., Walker, M. D., Chapin, F. S. \& Starfield, A. M. (2004). Detecting changes in arctic tundra plant communities in response to warming over decadal time scales. Global Change Biology, 10, 1325-1334.

Feng, S. \& Hu, Q. (2004). Changes in agro-meteorological indicators in the contiguous United States: 1951-2000. Theoretical Applications in Climatology, 78, 247-264. 
Flannigan, M. D., Stocks, B. J. \& Wotton, B. M. (2000). Climate change and forest fires. The Science of the Total Environment, 262, 221-229.

Frich, P., Alexander, L. V., Della-Marta, P., Gleason, B., Haylock, M., Tank, A. M. G. K. \& Peterson, T. (2002). Observed coherent changes in climatic extremes during the second half of the twentieth century. Climate Research, 19, 2559-2566.

Goetz, S. J., Bunn, A. G., Fiske, G. J. \& Houghton, R. A. (2005). Satellite-observed photosynthetic trends across boreal North America associated with climate and fire disturbance. Proceedings of the National Academy of Sciences of the United States of America, 102, 13521-13525.

Gong, D. Y. \& Shi, P. J. (2003). Northern hemispheric NDVI variations associated with large-scale climate indices in spring. International Journal of Remote Sensing, 24, 2559-2566.

Goudrian, J., Groot, J. J. R. \& Uithol, P. W. J., (2001). Productivity of Agro-Ecosystems. Terrestrial Global Productivity, 573.

Gregory, P. J., Ingram, J. S. I., Campbell, B., Goudrian, L. A., Hunt, J. J., Linder, S., Stafford, S., Smith, M., Sutherst, R. W. \& Valentin, C., (1999). Managed production systems. The Terrestrial Biosphere and Global Change: Implications for natural and managed ecosystems,

Guild, L. S., Cohen, W. B. \& Kauffman, J. B. (2004). Detection of deforestation and land conversion in Rondonia, Brazil using change detection techniques. International Journal of Remote Sensing, 25, 731-750.

Hansen, J., Ruedy, R., Glascoe, J. \& Sato, M. (1999). GISS Analysis of Surface Temperature Change. Journal of Geophysical Research, 104, 30997-31022.

Hicke, J. A., Asner, G. P., Randerson, J. T., Tucker, C. J., Los, S., Birdsey, R., Jenkins, J. C., Field, C. \& Holland, E. (2002). Satellite-derived increases in net primary productivity across North America 1982-1998. Geophysical Research Letters, 29, 1427.

Hobbie, S. E., Nadelhofer, K. J. \& Hogberg, P. (2002). A synthesis: The role of nutrients as constraints on carbon balances in boreal and arctic regions. Plant and Soil, 242, 163-170.

Houghton, R. A. (1999). The annual net flux of carbon to the atmosphere from changes in land use 1850-1990. Tellus Series B-Chemical and Physical Meteorology, 51B, 298-313.

Howard, E. A., Gower, S. T., Foley, J. A. \& Kucharik, C. J. (2004). Effects of logging on carbon dynamics of jack pine forest in Saskatchewan, Canada. Global Change Biology, 10, 1267-1284.

Huang, C., Wylie, B., Yang, L., Homer, C. \& Zylstra, G. (2002). Derivation of a tassellled cap transformation based on Landsat 7 at-satellite reflectance. International Journal of Remote Sensing, 23, 1741-1748.

Ichii, K., Kawabata, A. \& Yamaguchi, Y. (2002). Global correlation analysis for NDVI and climatic variables and NDVI trends:1982-1990. International Journal of Remote Sensing, 23, 3873-3878.

Imhoff, M. L., Tucker, C. J., Lawrence, W. T. \& Stutzer, D. C. (2000). The use of multisource satellite and geospatial data to study the effect of urbanization on primary productivity in the United States. Ieee Transactions on Geoscience and Remote Sensing, 38, 2549-2556.

Jarvis, P. G., Saugier, B. \& Schulze, E. D., (2001). Productivity of Boreal Forests. 573. Jensen, J. R., (2006). Remote Sensing of the Environment: An Earth Resource Perspective. 592. 
Jia, G. J., Epstein, H. E. \& Walker, D. A. (2003). Greening of Arctic Alaska, 1981-2001. Geophysical Research Letters, 30, hls3-1,3-4.

Jin, S. \& Sader, S. A. (2005). Comparison of time series tasseled cap wetness and the normalized difference moisture index in detecting forest disturbances. Remote Sensing of Environment, 94, 364-372.

Kasischke, E. S., French, N.H.F. (1997). Constraints on using AVHRR composite index imagery to study patterns of vegetation cover in boreal forests. International Journal of Remote Sensing, 18, 2403-2426.

Kauth, R. J., Lambeck, P. F., Richardson, W., Thomas, G. S. \& Pentland, A. P. (1978). Feature extraction applied to agricultural applied to agricultural crops as seen by Landsat. The LACIE Symposium Proceedings of the Technical Session, 705-722.

Kettela, E. (1983). A Cartographic History of Spruce Budworm Defoliation from 1967 to 1981 in Eastern North America. Canadian Forestry Service, 14.

Labus, M. P., Nielsen, G. A., Lawrence, R. L. \& Engel, R. (2002). Wheat yield estimates using multi-temporal NDVI satellite imagery. International Journal of Remote Sensing, 23, 4169-4180.

Lanjeri, S., Segarra, D. \& Mella, J. (2004). Interannual vineyard crop variability in the Castilla-La Mancha region during the period 1991-1996 with Landsat Thematic Mapper images. International Journal of Remote Sensing, 25, 2441-2457.

Larson, D. L. (1995). Effects of climate on numbers of northern prairie wetlands. Climatic Change, 30, 169-180.

Lemly, A. D., Kingsford, R. T. \& Thompson, J. R. (2000). Irrigated Agriculture and Wildlife Conservation: Conflict on a Global Scale. Environmental Management, 25, 485-512.

Lotsch, A., Friedl, M. A., Anderson, B. T. \& Tucker, C. J. (2005). Response of terrestrial ecosystems to recent Northern Hemispheric drought. Geophysical Research Letters, 32, L06705.

Lucht, W., Prentice, I. C., Myneni, R. B., Sitch, S., Friedlingstein, P., Cramer, W., Bousquet, P., Buermann, W. \& Smith, B. (2002). Climatic Control of the HighLatitude Vegetation Greening Trend and Pinatubo Effect. Science, 296, 16871689.

Lunetta, R. S., Ediriwickrema, J., Johnson, D. M., Lyon, H. J. G. \& McKerrow, A. (2002). Impacts of vegetation dynamics on the identification of land-cover change in a biologically complex community in North Carolina, USA. Remote Sensing of Environment, 82, 258-270.

Malhi, S. S., Gill, K. S. \& Heier, K. (2001). Effectiveness of banding versus broadcasting of establishment-time and annual phosphorus applications on yield, protein, and phosphorus uptake of bromegrass. Journal of Plant Nutrition, 24, 1435-1444.

Masek, J. G., Lindsay, F. E. \& Goward, S. N. (2000). Dynamics of urban growth in the Washington DC metropolitan area, 1973-1996, from Landsat observations. International Journal of Remote Sensing, 21, 3473-3486.

Menzel, A. \& Fabian, P. (1999). Growing season extended in Europe. Nature, 397, 659.

Monteith, J. L. (1981). Climatic variation and the growth of crops. Quarterly Journal of The Royal Meteorological Society, 107, 749-774.

Meteorological Service of Canada, (2007). Meteorological Service of Canada, Available Online at: http://www.msc-smc.ec.gc.ca (accessed 2-12-2007).

Myneni, R. B., Dong, J., Tucker, C. J., Kaufmann, R. K., Kauppi, P. E., Liski, J., Zhou, L., Alexeyev, V. \& Hughes, M. K. (2001). A large carbon sink in the woody 
biomass of Northern forests. Proceedings of the National Academy of Sciences of the United States of America, 98, 14784-14789.

Myneni, R. B., Hall, F. G., Sellers, P. J. \& Marshak, A. L. (1995). The Interpretation of Spectral Vegetation Indexes. IEEE Transactions Geoscience and Remote Sensing, 33, 481-486.

Myneni, R. B., Keeling, C. D., Tucker, C. J., Asrar, G. \& Nemani, R. R. (1997). Increased Plant Growth in the Northern High Latitudes from 1981 to 1991. Nature, 386, 698-702.

Nackerts, K., Vaesen, K., Muys, B. \& Coppin, P. (2005). Comparative performance of a modified change vector analysis in a forest change detection. International Journal of Remote Sensing, 26, 839-852.

Neigh, C. S. R., Tucker, C. J. \& Townshend, J. R. G. (2007). Synchronous NDVI and surface temperature trends in Newfoundland: 1982-2003. International Journal of Remote Sensing, in press, .

Nemani, R. R., Keeling, C. D., Hashimoto, H., Jolly, W. M., Piper, S. C., Tucker, C. J., Myneni, R. B. \& Running, S. W. (2003). Climate-Driven Increases in Global Terrestrial Net Primary Production from 1982 to 1999. Science, 300, 1560-1563.

Natural Resources Canada, (2006). Forestry Statistics, Available Online at: http://www.nrcan.gc.ca/cfs (accessed 11-29-06).

Odum, E. P. (1969). The Strategy of Ecosystem Development. Science, 164, 262-270.

Olson, J. S., (1975). Productivity of Forests Ecosystems, Productivity of World Ecosystems.

Opie, J., (2000). Ogallala: water for a dry land. 475.

Pavelsky, T. M. \& Smith, L. C. (2004). Spatial and temporal patterns in Arctic river ice breakup observed with MODIS and AVHRR time series. Remote Sensing of Environment, 93, 328-338.

Picket, S. T. A. \& White, P. S., (1985). The Ecology of Natural Disturbance and Patch Dynamics. 472.

Potter, C., Randerson, J., Field, C., Matson, P. A., Vitousek, P., Mooney, H. \& Klooster, S. (1993). Terrestrial ecosystem production: A process model based on global satellite and surface data. Global Biogeochemical Cycles, 11, 99-109.

Powell, R. L., Matzke, N., deSouza, C., Clark, M., Numata, I., Hess, L. L. \& Roberts, D. A. (2004). Sources of error in accuracy assessment of thematic land-cover maps in the Brazilian Amazon. Remote Sensing of Environment, 90, 221-234.

Rasmussen, M. S. (1992). Assessment of millet yields and production in northern Burkina Faso using integrated NDVI from the AVHRR. International Journal of Remote Sensing, 13, 3431-3442.

Richards, J. A. (1984). Thematic mapping from multitemporal image data using principal components transformation. Remote Sensing of Environment, 16, 35-46.

Richards, J. A., (1993). Remote sensing digital image analysis. An introduction. 340.

Rigina, O. (2003). Detection of boreal forest decline with high-resolution panchromatic satellite imagery. International Journal of Remote Sensing, 24, 1895-1912.

Sabol, D. E., Gillespie, A. R., Adams, J. B., Smith, M. O. \& Tucker, C. J. (2002). Structural stage in Pacific Northwest forest estimated using simple mixing models of multispectural images. Remote Sensing of Environment, 80, 1-16.

Sainju, U. M., Singh, B. P. \& Whitehead, W. F. (2002). Long-term effects of tillage, cover crops, and nitrogen fertilization on organic carbon and nitrogen concentrations in sandy loam soils in Georgia, USA. Soil and Tillage Research, $63,167-169$. 
Scanlon, B. R., Reedy, R. C., Stonestrom, D. A., Pridic, D. E. \& Dennehy, K. F. (2005). Impact of land use and land cover change on groundwater recharge and quality in the southwestern US. Global Change Biology, 11, 1577-1593.

Sellers, P. J. (1985). Canopy reflectance, photosynthesis, and transpiration. International Journal of Remote Sensing, 6, 1335-1372.

Sellers, P. J., Hall, F. G., Kelly, R. D., Black, A., Baldocchi, D., Berry, J., Ryan, M., Ranson, K. J., Crill, P. M., Lettenmaier, D. P., Margolis, H., Chilar, J., Newcomer, J., Fitzjarrald, D., Jarvis, P. G., Gower, S., Halliwell, D., Williams, D., Goodison, B., Wickland, D. E. \& Guertin, F. E. (1997). BOREAS in 1997: Experiment overview, scientific results, and future directions. Journal of Geophysical Research (JGR), BOREAS Special Issue II, 102, 28,731-728,769.

Slayback, D., Pinzon, J., Los, S. \& Tucker, C. J. (2003). Northern hemisphere photosynthetic trends 1982-99. Global Change Biology, 9, 1-15.

Stehman, S. V. \& Wickham, J. D. (2006). Assessing accuracy of net change derived from land cover maps Photogrammetric Engineering and Remote Sensing, 72, 175-185.

Stokstad, E. (2004). Deforesting the Carbon Freezer of the North. Science, 304, 16191620.

Stow, D., Daeschner, S., Hope, A., Douglas, D., Petersen, A., Myneni, R., Zhou,'L. \& Oechel, W. (2003). Variability of the Seasonality Integrated Normalized Difference Vegetation Index Across the North Slope of Alaska in the 1990s. International Journal of Remote Sensing, 24, 1111-1117.

Sturm, M., Douglas, T. \& Racine, R. (2005). Changing snow and shrub conditions affect albedo with global implications. Journal of Geophysical Research, 110, 1-13.

Sturm, M., McFadden, J. \& Liston, G. (2001). Snow-shrub interactions in Arctic tundra: a hypothesis with climatic implications. Journal of Climate, 14, 336-344.

Tape, K., Sturm, M. \& Racine, C. (2006). The evidence for shrub expansion in Northern Alaska and the Pan-Arctic. Global Change Biology, 12, 686-702.

Tilman, D. (1999). Global environmental impacts of agriculture expansion: The need for sustainable and efficient practices. Proceedings of the National Academy of Sciences of the United States of America, 96, 5995-6000.

Tou, J. T. \& Gonzales, R. C., (1974). Pattern Recognition Principles.

Townshend, J. R. G., Justice, C. O., Gurney, C. \& McManus, J. (1992). The Impact of Misregistration on Change Detection. IEEE Transactions Geoscience and Remote Sensing, 30, 1054-1060.

Trenberth, K. E., Branstator, G. W. \& Arkin, P. (1988). Origins of the 1988 North American Drought. Science, 242, 1640-1645.

Tucker, C. J. (1979). Red and Photographic Infrared Linear Combinations for Monitoring Vegetation. Remote Sensing of Environment, 8, 127-150.

Tucker, C. J., Grant, D. M. \& Dykstra, J. D. (2004). NASA's Global Orthorectified Landsat Data Set. Photogrammetric Engineering and Remote Sensing, 70, 313322.

Tucker, C. J., Pinzon, J. E., Brown, M. E., Slayback, D. A., Pak, E. W., Mahoney, R., Vermote, E. F. \& Saleous, N. E. (2005). An Extended AVHRR 8-km NDVI Data Set Compatible with MODIS and SPOT Vegetation NDVI Data. International Journal of Remote Sensing, 26, 4485-4498.

Tucker, C. J., Slayback, D. A., Pinzon, J. E., Los, S. O., Myneni, R. B. \& Taylor, M. G. (2001). Higher northern latitude normalized difference vegetation index and growing season trends from 1982 to 1999. International Journal of Biometeorology, 45, 184-190. 
USDA, (2006). National Agriculture Statistics, Available Online at: http://www.nass.usda.gov (accessed 11-29-06).

vanCleve, K., Oliver, L., Schlenter, R., Viereck, L. A. \& Dyrness, C. T. (1983).

Productivity and nutrient cycling in taiga forest ecosystems. Canadian Journal of Forest Research - Revue Canadienne De Recherche Forestiere, 13, 747-766.

Vowinckel, T., Oechel, W. C. \& Boll, W. G. (1975). The effect of climate on the photosynthesis of Picea mariana at the subartic tree line. Canadian Journal of Botany, 604-620.

Walker, D. A., Epstein, H. E., Jia, G. J., Balser, A., Copass, C., Edwards, E. J., Gould, W. A., Hollingsworth, J., Knudson, J., Maier, H. A., Moody, A. \& Raynolds, M. K. (2003). Phytomass, LAI, and NDVI in northern Alaska: Relationships to summer warmth, soil $\mathrm{pH}$, plant functional types, and extrapolation to the circumpolar Arctic. Journal of Geophysical Research-Atmospheres, 108,

Wang, J., Price, K. P. \& Rich, P. M. (2001). Spatial patterns of NDVI in response to precipitation and temperature in the central Great Plains. International Journal of Remote Sensing, 22, 3827-3844.

Warner, T. (2005). Hyperspherical direction cosine change vector analysis. International Journal of Remote Sensing, 26, 1201-1215.

Wein, R. W. \& MacLean, D. A., (1983). The Role of Fire in Northern Circumpolar Ecosystems.

Winter, T. C. \& Rosenberry, D. O. (1998). Hydrology of Prairie Pothole Wetlands During Drought and Deluge: A 17-year study of the cottonwood lake wetland complex in North Dakota in the perspective of longer term measured and proxy hydrological records. Climatic Change, 40, 189-209.

Wright, H. E. \& Heinselman, M. L. (1973). The ecological role of fire in natural conifer forests of western and northern North America. Quaternary Research, 3, 317-513.

Zhou, L., Kaufmann, R.K., Tian, Y., Myneni, R.B., and Tucker, C.J. (2003). Relation Between Interannual Variations in Satellite Measures of Vegetation Greenness and Climate Between 1982 and 1999. Journal of Geophysical Research, 108, ACL 3-1, ACL 3-11.

Zhou, L., Tucker, C. J., Kaufmann, R. K., Slayback, D., Shabanov, N. V. \& Myneni, R. B. (2001). Variations in northern vegetation activity inferred from satellite data of vegetation index during 1981 to 1999. Journal of Geophysical Research, 106, 20,069-020,083. 